\title{
Membrane Proteins as Potential Colon Cancer Biomarkers: Verification of 4 Candidates from a Secretome Dataset
}

\author{
Sum-Fu Chiang1,2, Ming-Hung Tsai' ${ }^{3}$, Reiping Tang1,4, Ling-Ling Hsieh5, Jy-Ming Chiang1, \\ Chien-Yuh Yeh"1, Pao-Shiu Hsieh"1, Wen-Sy Tsai1, Ya-Ping Liu', Ying Liang6, \\ Jinn-Shiun Chen ${ }^{*}$, Jau-Song $\mathbf{Y u}^{7^{*}}$ \\ ${ }^{1}$ Division of Colon and Rectal Surgery, Chang Gung Memorial Hospital, Linkou, Chinese Taipei \\ ${ }^{2}$ Graduate Institute of Clinical Medical Sciences, College of Medicine, Chang Gung University, Taoyuan, \\ Chinese Taipei \\ ${ }^{3}$ Graduate Institute of Biomedical Sciences, Chang Gung University, Taoyuan, Chinese Taipei \\ ${ }^{4}$ College of Medicine, Chang Gung University, Linkou, Chinese Taipei \\ ${ }^{5}$ Department of Public Health, Chang Gung University, Taoyuan, Chinese Taipei \\ ${ }^{6}$ Pathology Core of the Chang Gung Molecular Medicine Research Center, Taoyuan, Chinese Taipei \\ ${ }^{7}$ Department of Biochemistry and Molecular Biology, Chang Gung University, Taoyuan, Chinese Taipei \\ Email: ${ }^{*}$ chenjs@cgmh.org.tw,
}

Received 9 August 2014; revised 5 September 2014; accepted 1 October 2014

Copyright (C) 2014 by authors and Scientific Research Publishing Inc.

This work is licensed under the Creative Commons Attribution International License (CC BY).

http://creativecommons.org/licenses/by/4.0/

c) (i) Open Access

\begin{abstract}
Colorectal cancer (CRC) is an important health issue in Taiwan. There were over ten thousand newly diagnosed CRC patients each year. The outcome of late stage CRC still remains to be improved, and tumor markers are expected to improve CRC detection and management. From a colorectal cancer cell secretome database, we chose four proteins as candidates for clinical verification, including tumor-associated calcium signal transducer 2 (TROP2, TACSTD2), transmembrane 9 superfamily member 2 (TM9SF2), and tetraspanin-6 (TSPAN6), and tumor necrosis factor receptor superfamily member 16 (NGFR). Different groups of 30 CRC patients' tissue samples collected from Chang Gung Memorial Hospital were analyzed by immunohistochemistry (IHC) for the four proteins, and the results were scored by pathologist. For all the four candidate proteins, marked differences of IHC score existed between tumor and adjacent non-tumor counterpart. However, there were only trends between higher protein expression levels and worse outcome. Three proteins (TROP2, TM9SF2 and NGFR) had trends between higher tissue expression and tumor stage or lymph node metastasis. Our study revealed that tissue expression of four proteins (TROP2, TM9SF2, TSPAN6, and NGFR) was markedly different between tumor and adjacent non-tumor counterparts. Overexpression of all these four proteins showed some trends with poorer survival.
\end{abstract}

${ }^{*}$ Corresponding authors. 


\title{
Keywords
}

\author{
Biomarker, Colorectal Cancer, Immunohistochemistry, Membrane Protein, Secretome, \\ Tetraspanin-6, Transmembrane 9 Superfamily Member 2, Tumor-Associated Calcium Signal \\ Transducer 2, Tumor Necrosis Factor Receptor Superfamily Member 16, Verification
}

\section{Introduction}

In Taiwan, colorectal cancer (CRC) has become an important health issue in recent years. There were more and more newly diagnosed CRC every year. In 2011, there were 14,087 CRC patients diagnosed in Taiwan [1]. Among them, 49.5\% were diagnosed as late stage (stage III, 26.6\%; stage IV, 22.8\%). The five-year survival rate for late staged CRC was still relatively low (for colon cancer, stage III, 47.8\%; stage IV, 10.3\%) [2]. Tumor biomarkers were expected to integrate into CRC management to improve earlier diagnosis rate, to improve risk stratification, and to predict treatment response [3]-[7]. However, carcinoembryonic antigen (CEA), the most common serum biomarker currently used in clinic for CRC, doesn't meet all these clinical needs [8]-[12].

Although serum biomarkers play important role in cancer management, histology-based approaches are still the gold standard for tumor staging at present. Molecular staging provides an opportunity to personalized medicine and to maximize cost-effective management [13]-[16]. More and more analyses suggest that molecular approaches offer an advantage for stratifying patients further. Recently, some prospective studies have begun to predict risk of disease recurrence by molecular markers [17] [18]. For example, epidermal growth factor receptor (EGFR), which participates in signaling pathways that are deregulated in cancer cells and up-regulated in 50\% - 80\% CRC cases [19]-[24], has shown to be related to prognosis and therapeutic response of CRC patients [25] [26]. Many studies reported that Cetuximab, an antibody against EGFR, has additional benefit on CRC patients receiving chemotherapy [27] [28].

In recent years, the secretome-based approach has been proven to be a promising strategy for discovery of CRC biomarkers [29]-[31]. Using this approach, we have previously established a secretome dataset from 23 cancer cell lines, from which over one hundred proteins were selected identified from two CRC cell lines [29]. Among them, we had selected four protein candidates for verification, including tumor-associated calcium signal transducer 2 (TROP2, TACSTD2), transmembrane 9 superfamily member 2 (TM9SF2), tetraspanin-6 (TSPAN6), and tumor necrosis factor receptor superfamily member 16 (NGFR). These four proteins have been preliminarily examined in some CRC tissues in the Human Protein Atlas (HPA). Furthermore, there have been some reports about expression levels of TROP2 in different cancers including pancreatic cancer, CRC and ovarian carcinoma [32]-[35]. Tumor necrosis factor receptor superfamily member 16 (NGFR) has been studied in neurologic malignancy, which is also involved in cell growth control [36]-[39]. In functional aspect, TSPAN6 was found to be involved in cell motility [40] [41]. which may be related to tumor cell migration. We verified these four proteins in CRC tissues and their adjacent non-tumor counterparts by immunohistochemistry. We also analyzed the relationships between protein expression levels and clinicopathological factors of CRC patients.

\section{Material \& Methods}

\subsection{Patient Population and Clinical Specimen}

All clinical samples were collected at Chang Gung Memorial Hospital (Taoyuan, Taiwan). Tissue samples were collected in 1995. Different groups of 30 CRC patients' tissue samples were used for our candidates. All CRC patients had histologically verified adenocarcinoma. All were subjected to a follow-up strategy that included regular outpatient visits, CEA test, and image studies. Patients characteristics, including gender, age, tumor location, histological grade, tumor stage, CEA level, operation date, tumor recurrence, follow up date, and follow up status, were obtained from clinical and pathology records. The study was approved by the Institutional Review Board at Chang Gung Memorial Hospital (IRB No. 99-0515B, 101-0712B and 102-1446C).

\subsection{Immunohistochemistry}

The tumor tissue blocks used for IHC were first fixed in 4\% paraformaldehyde and then embedded in paraffin. 
Sections ( $5 \mu \mathrm{m}$ thick) were cut from tissue blocks, mounted on silanized slides (Superfrost, Menzel, Braunschweig, Germany), subsequently deparaffinized with xylene (twice for $10 \mathrm{~min}$ each), and rehydrated through ethanol gradient washes. Endogenous peroxidase activities are inactivated in $3 \% \mathrm{H}_{2} \mathrm{O}_{2}$ before heating in a microwave oven for antigen retrieval (10 mm citrate buffer, $\mathrm{pH}$ 6.0; $20 \mathrm{~min}, 700 \mathrm{~W})$. To block nonspecific binding, slides were preincubated with $10 \%$ nonimmune goat serum at $37^{\circ} \mathrm{C}$ for $30 \mathrm{~min}$. Slides were then incubated with anti-human primary antibody for 30 min at room temperature. Following washing with PBS (pH 7.4), slides were incubated with HRP-conjugated IgG secondary antibody for $30 \mathrm{~min}$ at room temperature and then developed using 3,3'-diaminobenzidine (Sigma, St Louis, MO). All procedure followed the standard pro-tocol. Expression of these protein was categorized as positive or negative and was evaluated according to the percentage of cells stained $(0 \%-100 \%)$ and the intensity of cell staining (3, strong; 2 , moderate; 1 , weak; or 0 , no cell staining).

\subsection{Statistical Analysis}

For the analysis of IHC results, independent $t$ test was used. The associations between protein expression and clinicopathological characteristics were analyzed using chi-square method and ANOVA. To determine factors related to overall survival, the probability was calculated using the Log-rank test by the Kaplan-Meier method. Cox proportional hazard models were used for maltivariate analysis. Comparative analysis of IHC scoring and CEA in paired CRC patients were undertaken. Statistical significance was set at $\mathrm{p}<0.05$. All analyses were performed using the statistical software, Statistical Package for the Social Sciences (Version 17.0, SPSS Inc., Chicago, IL).

\section{Results}

\subsection{Clinicopathological Analysis between High and Low Protein Expression Groups}

All patients of each studied group for four candidate were divided into high expression group and low expression group. We used medium IHC scoring as cut-off value of high and low expression. It were 100 for TROP2, 110 for TM9SF2, 150 for TSPAN6, 110 for NGFR. We analyzed most clinicopathologic factors, including ages, gender, tumor location, histological grade, tumor stage, $\mathrm{T}$ stage, $\mathrm{N}$ stage, CEA level, and survival. It seems no differences between high and low expression groups for each protein (Table 1).

\subsection{IHC Stain Scoring of Candidate Proteins between Tumor Tissues and Their Adjacent Non-Tumor Counterparts}

For all four candidate proteins, IHC scoring between adjacent non-tumor area (AN) and tumor area (T) was much different. For TROP2, it was $3.33 \pm 6.53$ vs. $92.67 \pm 22.06$ (AN vs. T, $\mathrm{p}<0.01$ ). For TM9SF2, it was $7.66 \pm$ 7.90 vs. $123.70 \pm 22.05$ (AN vs. T, $\mathrm{p}<0.01$ ). For TSPAN6, it was $3.33 \pm 6.53$ vs. $145.30 \pm 17.97$ (AN vs. T, $\mathrm{p}<$ 0.01). For NGFR, it was $6.00 \pm 5.44$ vs. $100.70 \pm 12.60$ (AN vs. T, p < 0.01) (Figure 1).

\subsection{Comparison of IHC Stained Area and Staining Scoring According to Different Clinicopathological Factors}

Furthermore, we compared mean proteins expression area and IHC scoring between different clinicopathologic factors. Although most factors had no statistical differences, patients with worse 5-year survival had trends of higher proteins expression area and IHC scoring. Patients with late tumor stage or positive lymph node metastasis had trends of higher protein expression (for TROP2, TM9SF2, NGFR). The trends also existed in histological grade (for TROP2 and NGFR) (Table 2).

\subsection{Kaplan-Meier Survival Analysis According to High and Low Protein Expression}

For all four proteins, high expression groups has the trend of worse survival, especial at 10-year. For TROP2, the 10-year survival rate of high expression and low expression groups were $28.5 \%$ vs. $50.0 \%(p=0.43)$. For TM9SF2, the 10-year survival rate of high expression and low expression groups were $18.0 \%$ vs. $42.0 \%(\mathrm{p}=$ 0.14). For TSPAN6, the 10-year survival rate of high expression and low expression groups were $22.0 \%$ vs. $33.0 \%$ $(p=0.60)$. For NGFR, the 10 -year survival rate of high expression and low expression groups were $52.9 \%$ vs. 
Table 1. Analysis of clinicopathologic factors of different proteins expression groups.

\begin{tabular}{|c|c|c|c|c|c|c|c|c|c|c|c|c|}
\hline \multirow{3}{*}{ Gender } & \multicolumn{3}{|c|}{ TROP2 } & \multicolumn{3}{|c|}{ TM9SF2 } & \multicolumn{3}{|c|}{ TSPAN6 } & \multicolumn{3}{|c|}{ NGFR } \\
\hline & Low & High & $\mathrm{p}$ & Low & High & $\mathrm{p}$ & Low & High & $\mathrm{p}$ & Low & High & $\mathrm{p}$ \\
\hline & & & & & & & & & & & & \\
\hline Male & $10(62.5)$ & $5(35.7)$ & \multirow{2}{*}{0.27} & $7(50.0)$ & $9(56.3)$ & \multirow{2}{*}{1.00} & 7 (58.3) & $12(66.7)$ & \multirow{2}{*}{0.71} & 7 (53.8) & $9(52.9)$ & \multirow{2}{*}{1.00} \\
\hline Female & $6(37.5)$ & $9(64.3)$ & & $7(50.0)$ & 7 (43.8) & & $5(41.7)$ & $6(33.3)$ & & $6(46.2)$ & $8(47.1)$ & \\
\hline \multicolumn{13}{|l|}{ Age } \\
\hline$<65$ & $5(31.3)$ & $4(28.6)$ & \multirow{2}{*}{1.00} & $6(42.9)$ & 7 (43.8) & \multirow{2}{*}{1.00} & $6(50.0)$ & $10(55.6)$ & \multirow{2}{*}{1.00} & $7(53.8)$ & $11(64.7)$ & \multirow{2}{*}{0.54} \\
\hline$\geq 65$ & $11(68.8)$ & $10(71.4)$ & & $8(57.1)$ & $9(56.3)$ & & $6(50.0)$ & $8(44.4)$ & & $6(46.2)$ & $6(35.3)$ & \\
\hline \multicolumn{13}{|l|}{ Location } \\
\hline Colon & $6(37.5)$ & $4(28.6)$ & \multirow{3}{*}{0.41} & $5(35.7)$ & $6(37.5)$ & \multirow{3}{*}{0.83} & $3(25.0)$ & $5(27.8)$ & \multirow{3}{*}{0.46} & 7 (53.8) & 9 (52.9) & \multirow{3}{*}{0.57} \\
\hline Rectum & $6(37.5)$ & $7(50.0)$ & & $7(50.0)$ & $9(56.3)$ & & $9(75.0)$ & $9(50.0)$ & & 5 (38.5) & 5 (29.4) & \\
\hline Other & $4(25.0)$ & $3(21.4)$ & & $2(14.3)$ & $1(6.2)$ & & $0(0)$ & $4(22.2)$ & & $1(7.7)$ & $3(17.7)$ & \\
\hline \multicolumn{13}{|c|}{ Histological grade } \\
\hline WD & $2(12.5)$ & $2(14.3)$ & \multirow{3}{*}{0.37} & $5(35.7)$ & $3(18.8)$ & \multirow{3}{*}{0.12} & 4 (33.3) & $5(27.8)$ & \multirow{3}{*}{0.53} & $4(30.8)$ & $4(23.5)$ & \multirow{3}{*}{0.60} \\
\hline MD & 14 (87.5) & $9(64.3)$ & & $7(50.0)$ & 13 (81.2) & & 7 (58.3) & $13(72.2)$ & & $9(69.2)$ & $11(64.7)$ & \\
\hline PD & $0(0)$ & $1(7.1)$ & & $2(14.3)$ & $0(0)$ & & $1(8.4)$ & $0(0)$ & & $0(0)$ & 2 (11.8) & \\
\hline \multicolumn{13}{|l|}{ Stage } \\
\hline Early & $6(37.5)$ & $6(42.9)$ & \multirow{2}{*}{1.00} & $8(57.1)$ & $8(50.0)$ & \multirow{2}{*}{0.73} & $3(25.0)$ & $6(33.3)$ & 070 & $9(69.2)$ & 12 (70.6) & \\
\hline Late & $10(62.5)$ & 8 (57.1) & & 6 (42.9) & $8(50.0)$ & & $9(75.0)$ & 12 (66.7) & 0.70 & $4(30.8)$ & 5 (29.4) & 1.00 \\
\hline T stage & & & & & & & & & & & & \\
\hline $\mathrm{T} 1-\mathrm{T} 2$ & $6(37.5)$ & $6(42.9)$ & 100 & 3 (21.4) & 2 (13.3) & 055 & $2(20.0)$ & $2(14.3)$ & & $1(7.7)$ & 3 (18.8) & \\
\hline T3-T4 & $10(62.5)$ & $8(57.1)$ & 1000 & 11 (78.6) & 13 (86.7) & 0.00 & $8(80.0)$ & 12 (85.8) & 1.00 & 12 (92.3) & 13 (81.3) & 0.00 \\
\hline Lymph no & e metastasis & & & & & & & & & & & \\
\hline Negative & $9(56.2)$ & $8(57.1)$ & & $8(57.1)$ & $8(50.0)$ & & $3(25.0)$ & $9(50.0)$ & & $9(69.2)$ & $12(70.6)$ & \\
\hline Positive & 7 (43.8) & $6(42.9)$ & 1.00 & 6 (42.9) & $8(50.0)$ & 0.05 & $9(75.0)$ & $9(50.0)$ & 0.20 & $4(30.8)$ & $5(29.4)$ & 1.00 \\
\hline CEA & & & & & & & & & & & & \\
\hline$<5$ & $10(62.5)$ & $6(42.9)$ & & $9(64.3)$ & $6(37.5)$ & & $6(50.0)$ & $11(61.1)$ & & 7 (53.8) & $7(41.2)$ & \\
\hline$\geq 5$ & $6(37.5)$ & 8 (57.1) & 0.40 & $5(35.7)$ & 9 (56.3) & 0.27 & $6(50.0)$ & 7 (38.9) & $0 . / 1$ & $6(46.2)$ & $9(52.9)$ & 0.83 \\
\hline 5-year sury & & & & & & & & & & & & \\
\hline$<5$ & $6(37.5)$ & $6(42.9)$ & & $6(42.9)$ & $10(62.5)$ & & $6(50.0)$ & 11 (61.1) & & $4(30.8)$ & $8(47.1)$ & \\
\hline$\geq 5$ & $10(62.5)$ & $8(57.1)$ & 1.00 & $8(57.1)$ & $6(37.5)$ & 0.40 & $6(50.0)$ & 7 (38.9) & 0.11 & $9(69.2)$ & $9(52.9)$ & 0.00 \\
\hline
\end{tabular}

$61.5 \%(p=0.62)$ (Figure 2).

\subsection{Multivariate Analysis}

Using 5-year survival as end point, we further did multivariate analysis for all four proteins (Table 3). However, TROP2 and NGFR didn't show any differences. High TM9SF2 expression group had HR $1.22(\mathrm{p}=0.72)$. High TSPAN6 expression group had HR $3.75(\mathrm{p}=0.02)$.

\subsection{Comparison Analysis with CEA}

All four proteins tissue expression seemed not to be related to CEA level. However, all candidates increased 
Table 2. Comparison of protein IHC scaring according to different clinicopathologic factors.

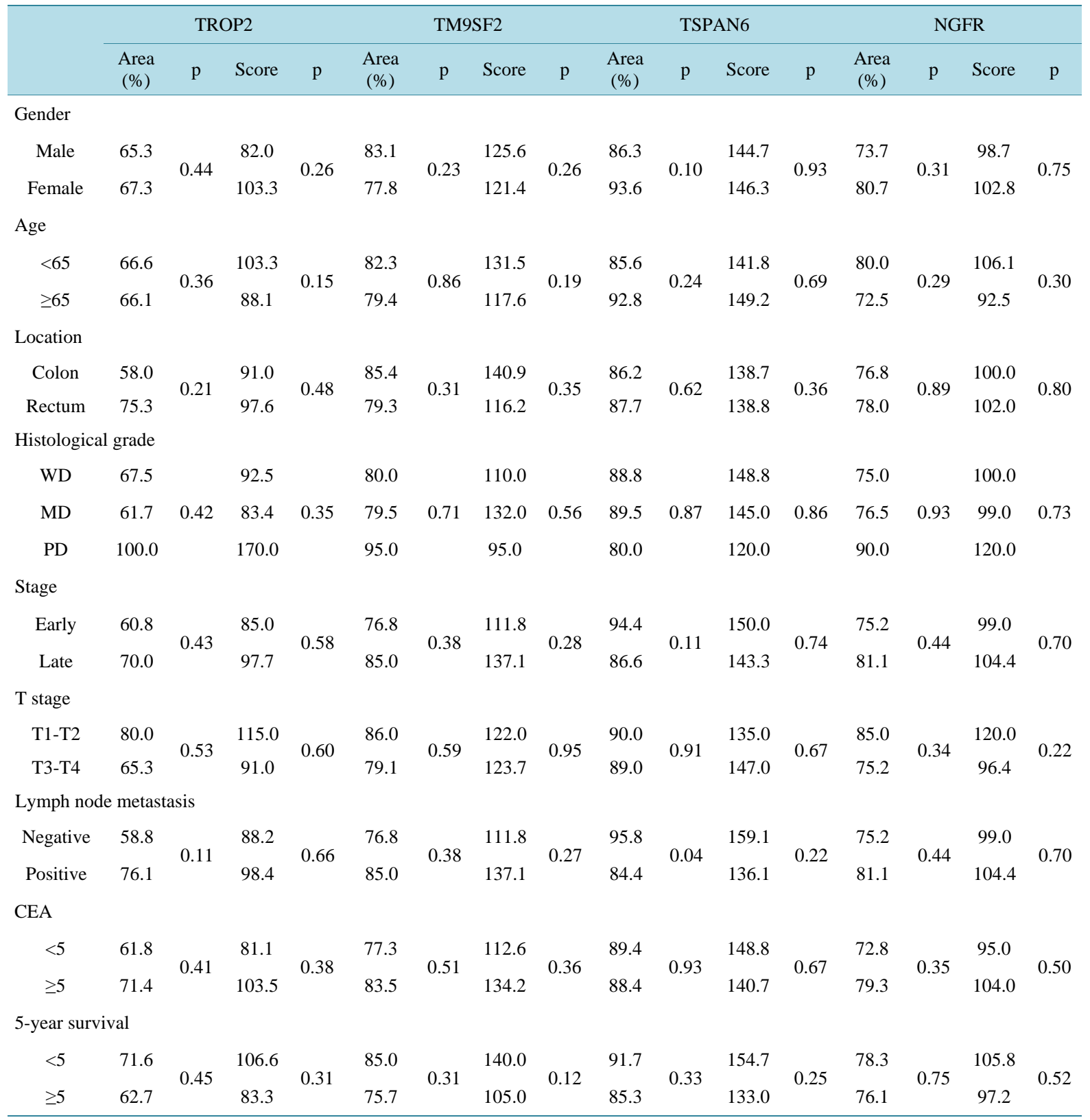

detection of normal CEA cases. We used medium IHC scoring as cut off for each protein. They were 100 for TROP2, 110 for TM9SF2, 150 for TSPAN6, and 110 for NGFR, respectively. For TROP2, 6 among 16 normal CEA cases had higher TROP2 tissue expression. For TM9SF2, 6 among 15 normal CEA cases had higher tissue expression. For TSPAN6, 11 among 17 normal CEA cases had higher tissue expression. For NGFR, 7 among 14 normal CEA cases had higher tissue expression (Figure 3). All four proteins had the potential to improve false negative rate of CEA.

\subsection{Expression Analysis among Stages with Normal and Abnormal CEA Levels}

We further analyzed the percentage of high and low expression among early stage and late stage cases. We found that, for TROP2 and TM9SF2, late stage with abnormal CEA had high tissue protein expression, compared to early stage with normal. But it seemed not to be different for NGFR, and even to have reverse association 

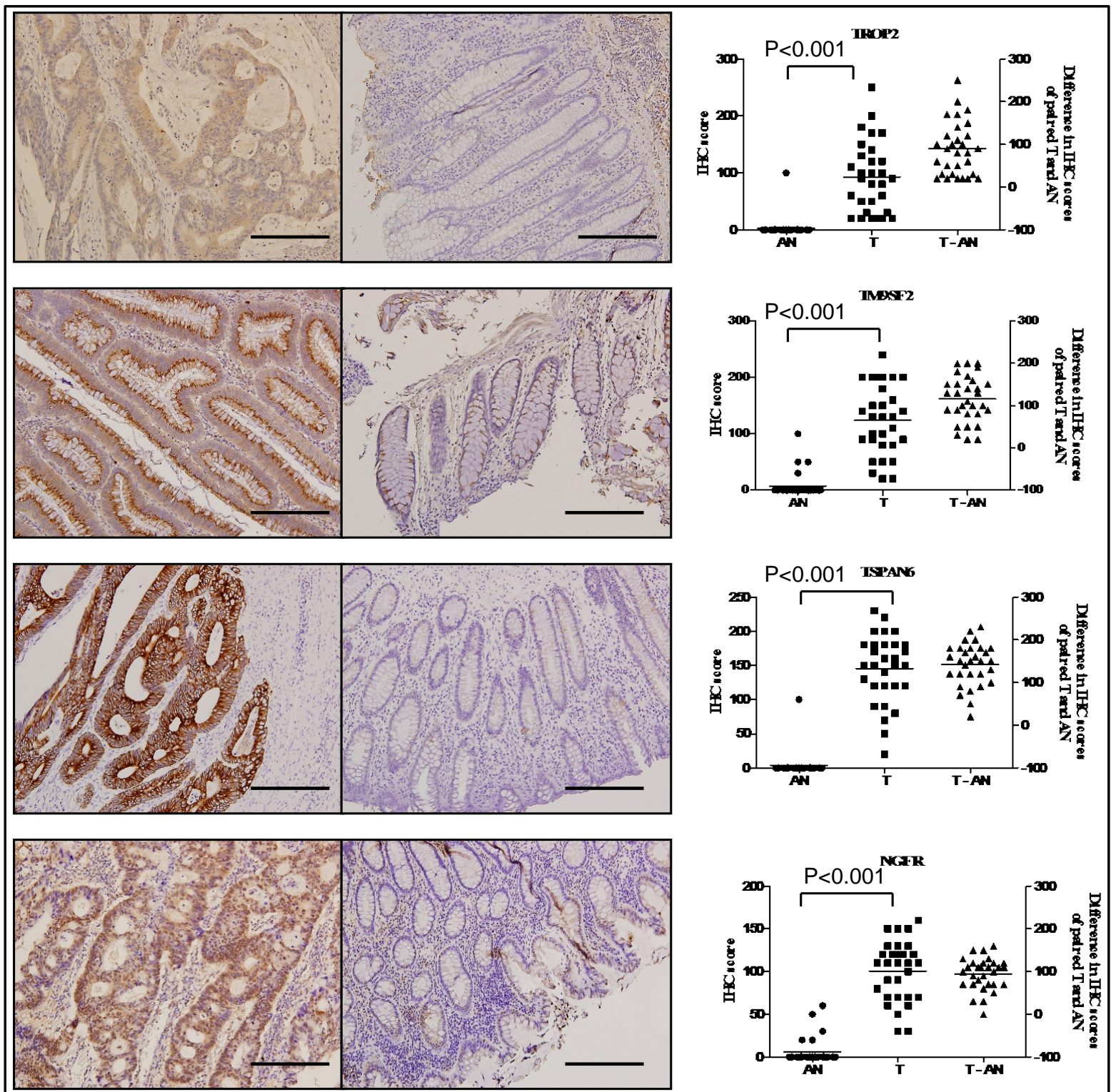

$200 \mu \mathrm{m}$

Figure 1. Immunohistochemical staining of TROP2 (A), TM9SF2 (B), TSPAN6 (C), and NGFR (D) in paired tumor (T) and adjuvant non-tumor (AN) tissues from different groups of 30 paired CRC patients (scale bar $=200 \mu \mathrm{m}$ ). All these four proteins were expressed mainly in cytosol of tumor cells (A)-(D). The IHC scores were markedly different between tumor and adjuvant non-tumor tissues. For TROP2, it was $3.33 \pm 6.53$ vs. $92.67 \pm 22.06$ (AN vs. T, p < 0.01) (E). For TM9SF2, it was $7.66 \pm 7.90$ vs. $123.70 \pm 22.05$ (AN vs. T, p < 0.01) (F). For TSPAN6, it was $3.33 \pm 6.53$ vs. $145.30 \pm 17.97$ (AN vs. T, $\mathrm{p}<0.01$ ) (G). For NGFR, it was $6.00 \pm 5.44$ vs. $100.70 \pm 12.60$ (AN vs. T, p $<0.01$ ) (H).

for TSPAN6 (Figure 4).

\section{Discussion}

At present, more and more biomarkers were analyzed in clinical setting. EGFR, which participates in signaling pathways, has shown to be associated with treatment response [19] [20]. These tumor biomarkers, especially on 
Table 3. Multivariate analysis.

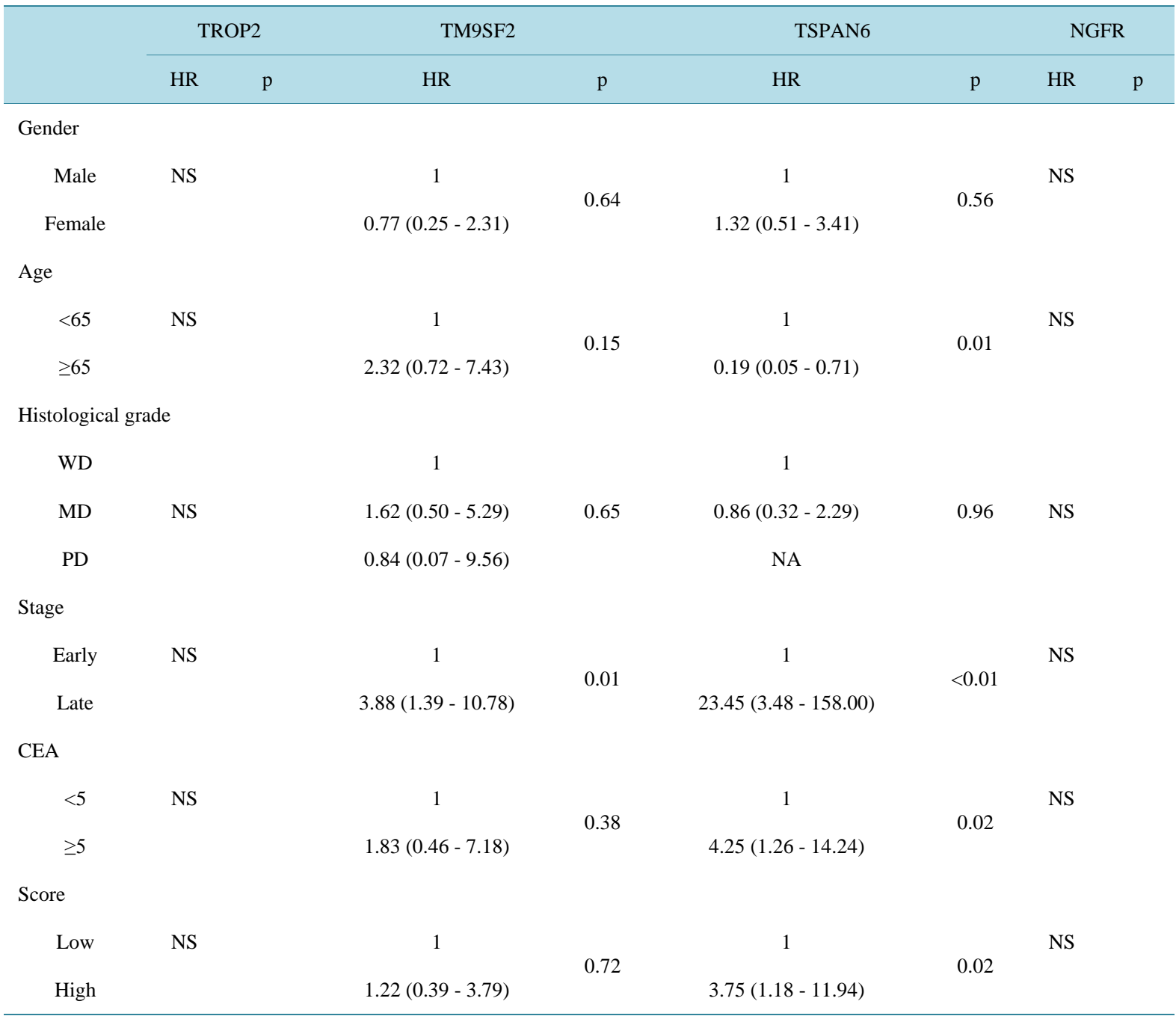

NS: not significant. NA: not available.

tissue level, were expected to improve earlier diagnosis rate and to make management more individualized [5] [7] [15].

Our study verified four membrane proteins from a secretome dataset in tissue level. The IHC scores of four candidate proteins were markedly different between tumor and adjuvant normal. Although further analysis did not show statistical difference, all of these proteins showed some trends with poorer survival. Except TSPAN6, other three proteins (TROP2, TM9SF2, NGFR) showed some trends with tumor aggressiveness (tumor stage, lymph node metastasis). Statistical insignificance might be due to small sample sizes.

In the literature, several tissue biomarkers had been verified in CRC (Supplement Table 1). Most of them are associated with survival or prognosis (Supplement Table 1). At present, tissue markers, not serum markers, can be used as a predictor of treatment response. For example, tissue expression of EGFR, which had been verified as biomarker of treatment response [27], was also a biomarker of survival. Survivin, an inhibitor of apoptosis, is known to be expressed in most tumor cell types. Several studies had shown its potential as a target for cancer therapy [42] [43]. Tissue biomarkers, which were tested more widely, seem to have the potential to be integrated in CRC management. Unlike serum markers, tissue markers research is more likely to be a straightforward strategy for treatment markers discovery.

Our data didn't usually show consistency between four candidates and different analyses. And p values were not significant because of small sample sizes. However, marked IHC scoring differences existed between tumor 

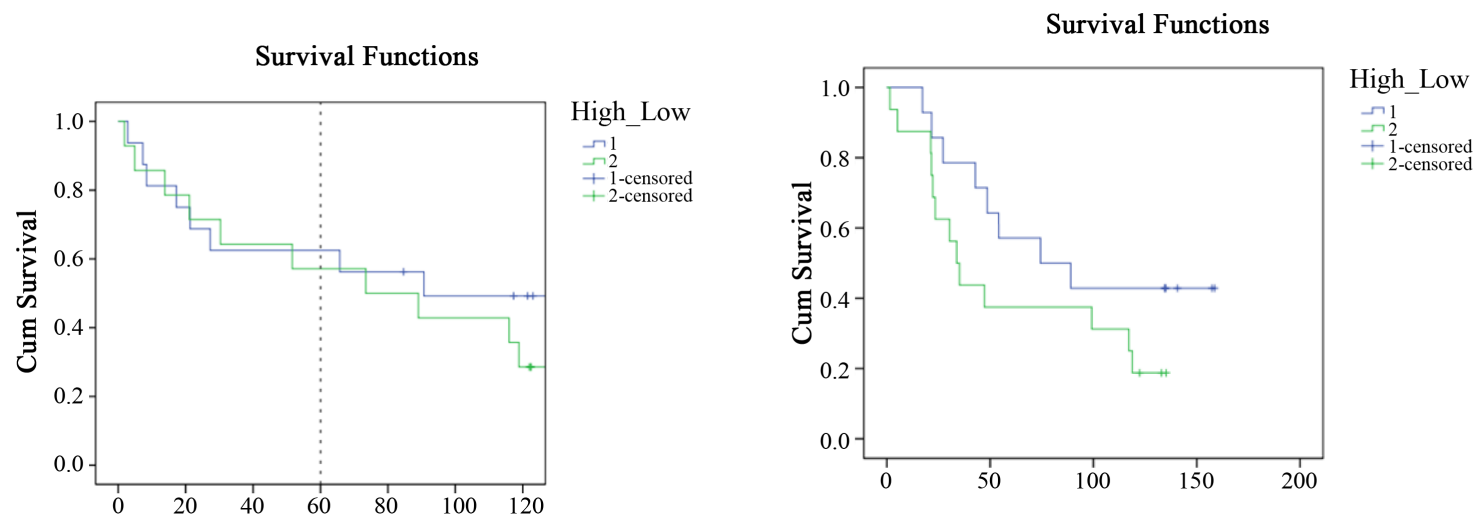

\begin{tabular}{|c|c|c|c|}
\hline & $\mathrm{n}$ & 5-year survival (\%) & 10-year survival (\%) \\
\hline Low expression & 16 & 62.5 & 50.0 \\
\hline High expression & 14 & 57.1 & 28.5 \\
\hline
\end{tabular}

\begin{tabular}{|c|c|c|c|}
\hline & $\mathrm{n}$ & 5-year survival (\%) & 10-year survival (\%) \\
\hline Low expression & 14 & $8 / 14$ & $6 / 14$ \\
\hline High expression & 16 & $6 / 16$ & $3 / 16$ \\
\hline
\end{tabular}

$$
\mathrm{P}=0.43 \text { (Log Rank test) }
$$

(a)

$$
\mathrm{P}=0.14 \text { (Log Rank test) }
$$

\section{Survival Functions}

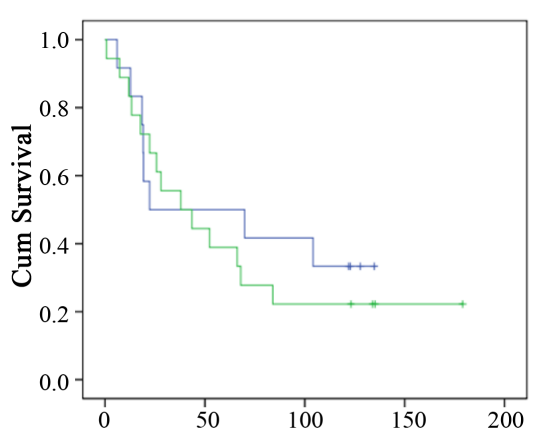

\begin{tabular}{|c|c|c|c|}
\hline & $\mathrm{n}$ & 5 -year survival (\%) & 10-year survival (\%) \\
\hline Low expression & 12 & $6 / 12$ & $4 / 12$ \\
\hline High expression & 18 & $7 / 18$ & $4 / 18$ \\
\hline
\end{tabular}

$\mathrm{P}=0.60$ (Log Rank test)
High Low

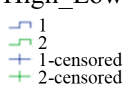

Survival Functions

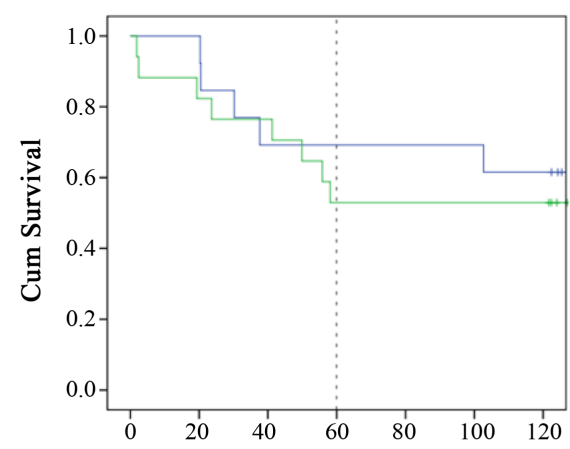

High_Low<smiles>C1[Si]C[Si]1</smiles>

+1 -censored
+2 -censored

\begin{tabular}{|c|c|c|c|}
\hline & $\mathrm{n}$ & 5-year survival (\%) & 10-year survival (\%) \\
\hline Low expression & 13 & 69.2 & 61.5 \\
\hline High expression & 17 & 52.9 & 52.9 \\
\hline
\end{tabular}

$\mathrm{P}=0.62$ (Log Rank test)

(d)

(c)

Figure 2. Kaplan-Meier survival analysis of different protein expression groups. The 10-year survival rate of high expression and low expression groups were $28.5 \%$ vs. $50.0 \%(p=0.43)$ for TROP2 (a), $42.0 \%$ vs. $18.0 \%(p=0.14)$ for TM9SF2 (b), $33.0 \%$ vs. $22.0 \%(p=0.60)$ for TSPAN6 (c), and $61.5 \%$ vs. $52.9 \%(p=0.62)$ for NGFR (d).

and adjuvant normal, and most candidates showed some trends with tumor aggressiveness and survival. In comparison analysis with CEA, our candidate proteins also showed the potential of improving false negative 
TROP2

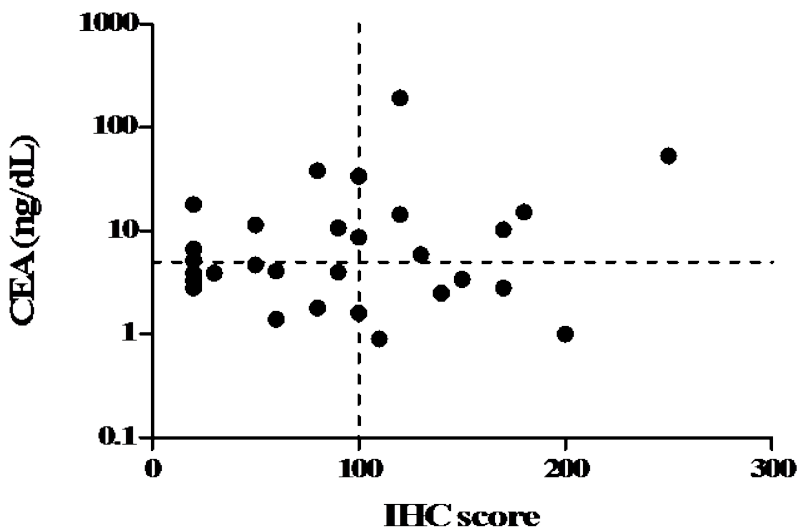

(a)

TSPAN6

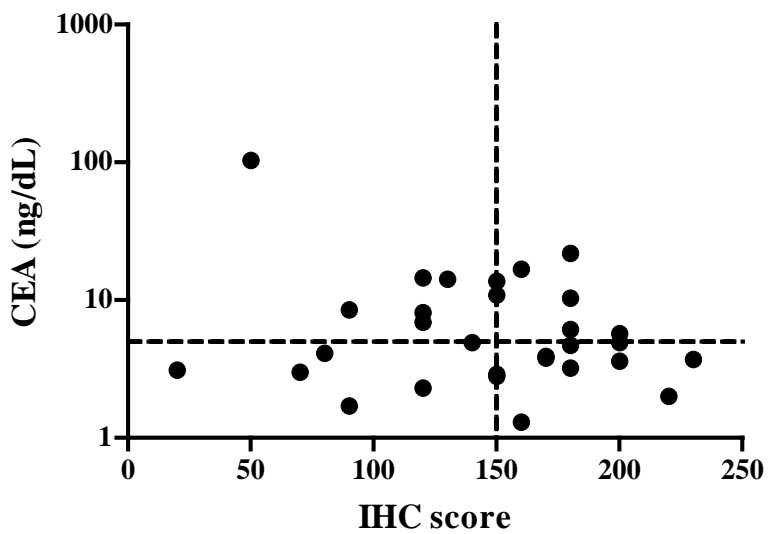

(c)
IMPSF2

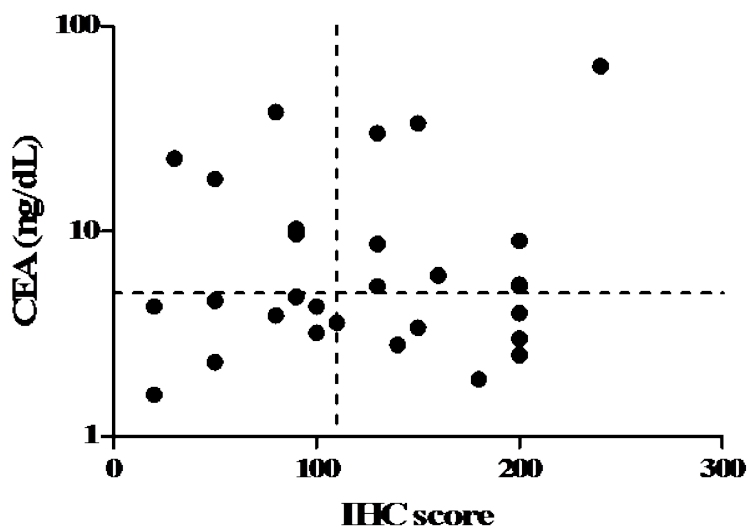

(b)

NGFR

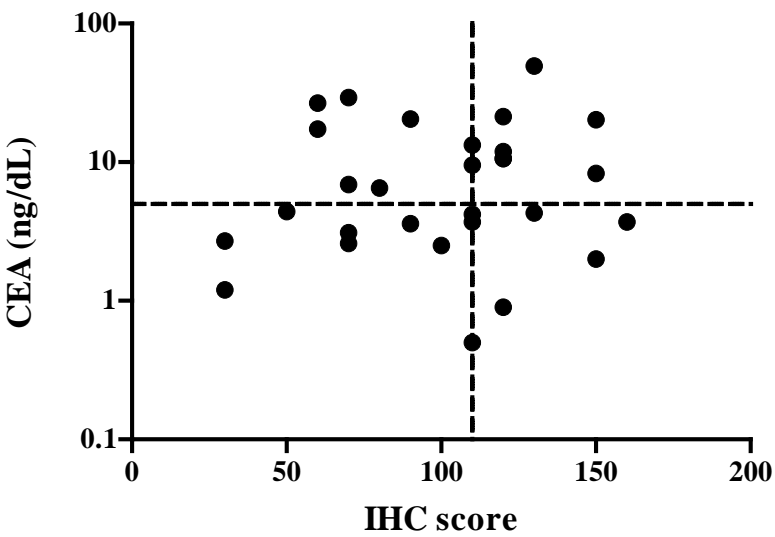

(d)

Figure 3. Medium IHC scores were used as cut off values for each proteins. (a) For TROP2, 6 among 16 normal CEA cases had higher TROP2 tissue expression. (b) For TM9SF2, 6 among 15 normal CEA cases had higher tissue expression. (c) For TSPAN6, 11 among 17 normal CEA cases had higher tissue expression. (d) For NGFR, 7 among 14 normal CEA cases had higher tissue expression.

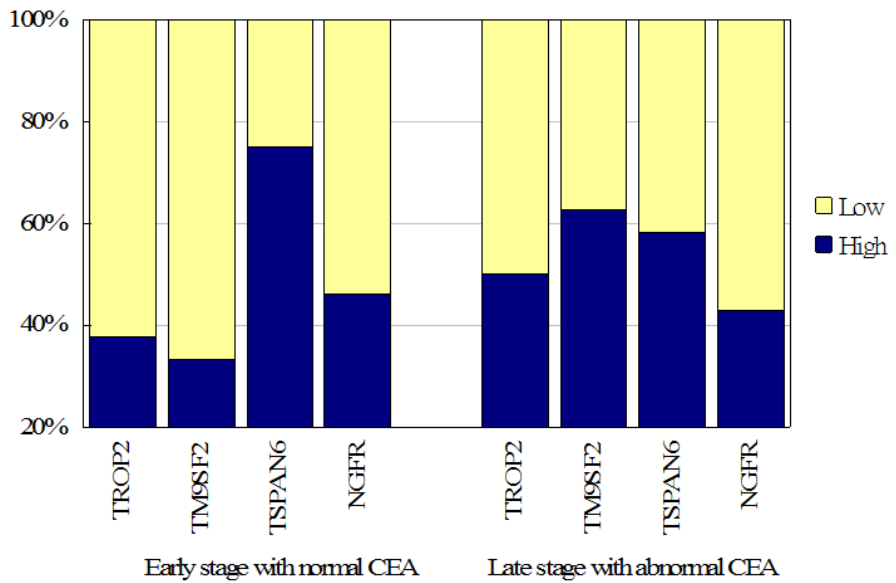

Figure 4. Comparison of the percentages of high and low protein expression. For TROP2 and TM9SF2, more percentages of high protein expression were found in late stage CRC patients with abnormal CEA. For TSPAN6 and NGFR, the associations were reverse. 
rate of CEA. More cases to be tested are needful. These four membrane proteins still have the potential to be novel CRC biomarkers. More studies are needed to integrate these proteins in clinical usage. The association between serum and tissue expression is the next interesting issue.

\section{Acknowledgements}

This work was supported by grants from Chang Gung Memorial Hospital (CMRPG290211 and CMRPG3B0751) and by the grant (EMRPD1C0011) from Chang Gung University. We are extremely grateful to the staff in Division of Colon and Rectal Surgery, Chang Gung Memorial Hospital. We are also grateful to the effort of Proteomics Core Lab and Pathology Core Lab, Chang Gung University.

\section{References}

[1] Health Promotion Administration, Ministry of Health and Welfare, Taiwan, R.O.C. http://www.hpa.gov.tw/BHPNet/Web/Index/Index.aspx

[2] Hyodo, I., Suzuki, H., Takahashi, K., et al. (2010) Present Status and Perspectives of Colorectal Cancer in Asia: Colorectal Cancer Working Group Report in 30th Asia-Pacific Cancer Conference. Japanese Journal of Clinical Oncology, 40, i38-i43. http://dx.doi.org/10.1093/jjco/hyq125

[3] Tänzer, M., Liebl, M. and Quante, M. (2013) Molecular Biomarkers in Esophageal, Gastric, and Colorectal Adenocarcinoma. Pharmacology \& Therapeutics, 140, 133-147. http://dx.doi.org/10.1016/j.pharmthera.2013.06.005

[4] Luo, Y., Wang, L. and Wang, J. (2013) Developing Proteomics-Based Biomarkers for Colorectal Neoplasms for Clinical Practice: Opportunities and Challenges. PROTEOMICS—Clinical Applications, 7, 30-41. http://dx.doi.org/10.1002/prca.201200071

[5] de Wit, M., Fijneman, R.J., Verheul, H.M., Meijer, G.A. and Jimenez, C.R. (2013) Proteomics in Colorectal Cancer Translational Research: Biomarker Discovery for Clinical Applications. Clinical Biochemistry, 46, 466-479. http://dx.doi.org/10.1016/j.clinbiochem.2012.10.039

[6] Manne, U., Shanmugam, C., Katkoori, V.R., Bumpers, H.L. and Grizzle, W.E. (2010) Development and Progression of Colorectal Neoplasia. Cancer Biomarks, 9, 235-265.

[7] Duffy, M.J., van Dalen, A., Haglund, C., et al. (2007) Tumour Markers in Colorectal Cancer: European Group on Tumour Markers (EGTM) Guidelines for Clinical Use. European Journal of Cancer, 43, 1348-1360. http://dx.doi.org/10.1016/j.ejca.2007.03.021

[8] Wang, J.Y., Tang, R. and Chiang, J.M. (1994) Value of Carcinoembryonic Antigen in the Management of Colorectal Cancer. Diseases of the Colon \& Rectum, 37, 272-277. http://dx.doi.org/10.1007/BF02048166

[9] Ballesta, A.M., Molina, R., Filella, X., Jo, J. and Giménez, N. (1995) Carcinoembryonic Antigen in Staging and FollowUp of Patients with Solid Tumors. Tumor Biology, 16, 32-41. http://dx.doi.org/10.1159/000217926

[10] Woolfson, K. (1991) Tumor Markers in Cancer of the Colon and Rectum. Diseases of the Colon \& Rectum, 34, 506511. http://dx.doi.org/10.1007/BF02049939

[11] Fletcher, R.H. (1986) Carcinoembryonic Antigen. Annals of Internal Medicine, 104, 66-73. http://dx.doi.org/10.7326/0003-4819-104-1-66

[12] Macdonald, J.S. (1999) Carcinoembryonic Antigen Screening: Pros and Cons. Seminars in Oncology, 26, 556-560.

[13] Iddings, D. and Bilchik, A. (2007) The Biologic Significance of Micrometastatic Disease and Sentinel Lymph Node Technology on Colorectal Cancer. Journal of Surgical Oncology, 96, 671-677. http://dx.doi.org/10.1002/jso.20918

[14] Hyslop, T. and Waldman, S.A. (2013) Molecular Staging of Node Negative Patients with Colorectal Cancer. Journal of Cancer, 4, 193-199. http://dx.doi.org/10.7150/jca.5830

[15] Akiyoshi, T., Kobunai, T. and Watanabe, T. (2012) Recent Approaches to Identifying Biomarkers for High-Risk Stage II Colon Cancer. Surgery Today, 42, 1037-1045. http://dx.doi.org/10.1007/s00595-012-0324-4

[16] Ahmed, F.E. (2005) Molecular Markers That Predict Response to Colon Cancer Therapy. Expert Review of Molecular Diagnostics, 5, 353-375. http://dx.doi.org/10.1586/14737159.5.3.353

[17] Waldman, S.A., Hyslop, T., Schulz, S., Barkun, A., Nielsen, K., Haaf, J., et al. (2009) Association of GUCY2C Expression in Lymph Nodes with Time to Recurrence and Disease-Free Survival in pN0 Colorectal Cancer. JAMA, 301, 745-752. http://dx.doi.org/10.1001/jama.2009.141

[18] Mejia, A., Schulz, S., Hyslop, T., Weinberg, D.S. and Waldman, S.A. (2012) Molecular Staging Individualizing Cancer Management. Journal of Surgical Oncology, 105, 468-474. http://dx.doi.org/10.1002/jso.21858

[19] Yarom, N. and Jonker, D.J. (2011) The Role of the Epidermal Growth Factor Receptor in the Mechanism and Treat- 
ment of Colorectal Cancer. Discovery Medicine, 11, 95-105.

[20] Vincenzi, B., Santini, D., Rabitti, C., Coppola, R., Beomonte Zobel, B., Trodella, L. and Tonini, G. (2006) Cetuximab and Irinotecan as Third-Line Therapy in Advanced Colorectal Cancer Patients: A Single Centre Phase II Trial. British Journal of Cancer, 94, 792-797. http://dx.doi.org/10.1038/sj.bjc.6603018

[21] Spano, J.P., Lagorce, C., Atlan, D., Milano, G., Domont, J., Benamouzig, R., et al. (2005) Impact of EGFR Expression on Colorectal Cancer Patient Prognosis and Survival. Annals of Oncology, 16, 102-108. http://dx.doi.org/10.1093/annonc/mdi006

[22] Scartozzi, M., Bearzi, I., Berardi, R., Mandolesi, A., Fabris, G. and Cascinu, S. (2004) Epidermal Growth Factor Receptor (EGFR) Status in Primary Colorectal Tumors Does Not Correlate with EGFR Expression in Related Metastatic Sites: Implications for Treatment with EGFR-Targeted Monoclonal Antibodies. Journal of Clinical Oncology, 22, 4772-4778. http://dx.doi.org/10.1200/JCO.2004.00.117

[23] McKay, J.A., Murray, L.J., Curran, S., Ross, V.G., Clark, C., Murray, G.I., Cassidy, J. and McLeod, H.L. (2002) Evaluation of the Epidermal Growth Factor Receptor (EGFR) in Colorectal Tumours and Lymph Node Metastases. European Journal of Cancer, 38, 2258-2264. http://dx.doi.org/10.1016/S0959-8049(02)00234-4

[24] Porebska, I., Harlozińska, A. and Bojarowski, T. (2000) Expression of the Tyrosine Kinase Activity Growth Factor Receptors (EGFR, ERB B2, ERB B3) in Colorectal Adenocarcinomas and Adenomas. Tumor Biology, 21, 105-115. http://dx.doi.org/10.1159/000030116

[25] Cunningham, D., Humblet, Y., Siena, S., Khayat, D., Bleiberg, H., Santoro, A., et al. (2004) Cetuximab Monotherapy and Cetuximab Plus Irinotecan in Irinotecan-Refractory Metastatic Colorectal Cancer. New England Journal of Medicine, 351, 337-345. http://dx.doi.org/10.1056/NEJMoa033025

[26] Yan, L. and Beckman, R.A. (2005) Pharmacogenetics and Pharmacogenomics in Oncology Therapeutic Antibody Development. BioTechniques, 39, S565-S568. http://dx.doi.org/10.2144/000112043

[27] Saltz, L.B., Meropol, N.J., Loehrer Sr., P.J., Needle, M.N., Kopit, J. and Mayer, R.J. (2004) Phase II Trial of Cetuximab in Patients with Refractory Colorectal Cancer that Expresses the Epidermal Growth Factor Receptor. Journal of Clinical Oncology, 22, 1201-1208. http://dx.doi.org/10.1200/JCO.2004.10.182

[28] Siddiqui, A.D. and Piperdi, B. (2010) KRAS Mutation in Colon Cancer: A Marker of Resistance to EGFR-I Therapy. Annals of Surgical Oncology, 17, 1168-1176. http://dx.doi.org/10.1245/s10434-009-0811-z

[29] Wu, C.C., Hsu, C.W., Chen, C.D., Yu, C.J., Chang, K.P., Tai, D.I., et al. (2010) Candidate Serological Biomarkers for Cancer Identified from the Secretomes of 23 Cancer Cell Lines and the Human Protein Atlas. Molecular \& Cellular Proteomics, 9, 1100-1117. http://dx.doi.org/10.1074/mcp.M900398-MCP200

[30] Xue, H., Lu, B., Zhang, J., Wu, M.L., Huang, Q., Wu, Q., et al. (2010) Identification of Serum Biomarkers for Colorectal Cancer Metastasis Using a Differential Secretome Approach. Journal of Proteome Research, 9, 545-555. http://dx.doi.org/10.1021/pr9008817

[31] Jimenez, C.R., Knol, J.C., Meijer, G.A. and Fijneman, R.J. (2010) Proteomics of Colorectal Cancer: Overview of Discovery Studies and Identification of Commonly Identified Cancer-Associated Proteins and Candidate CRC Serum Markers. Journal of Proteomics, 73, 1873-1895. http://dx.doi.org/10.1016/j.jprot.2010.06.004

[32] Fong, D., Moser, P., Krammel, C., Gostner, J.M., Margreiter, R., Mitterer, M., Gastl, G. and Spizzo, G. (2008) High Expression of TROP2 Correlates with Poor Prognosis in Pancreatic Cancer. British Journal of Cancer, 99, 1290-1295. http://dx.doi.org/10.1038/sj.bjc.6604677

[33] Fang, Y.J., Wang, G.Q., Lu, Z.H., Zhang, L., Li, J.B., Wu, X.J., et al. (2012) Different Effects of ER $\beta$ and TROP2 Expression in Chinese Patients with Early-Stage Colon Cancer. Tumor Biology, 33, 2227-2235. http://dx.doi.org/10.1007/s13277-012-0484-2

[34] Cubas, R., Zhang, S., Li, M., Chen, C.Y. and Yao, Q.Z. (2011) Chimeric Trop2 Virus-Like Particles: A Potential Immunotherapeutic Approach against Pancreatic Cancer. Journal of Immunotherapy, 34, 251-263. http://dx.doi.org/10.1097/CJI.0b013e318209ee72

[35] Bignotti, E., Todeschini, P., Calza, S., Falchetti, M., Ravanini, M., Tassi, R.A., et al. (2010) Trop-2 Overexpression as an Independent Marker for Poor Overall Survival in Ovarian Carcinoma Patients. European Journal of Cancer, 46, 944-953. http://dx.doi.org/10.1016/j.ejca.2009.12.019

[36] Thompson, S.J., Schatteman, G.C., Gown, A.M. and Bothwell, M. (1989) A Monoclonal Antibody against Nerve Growth Factor Receptor. Immunohistochemical Analysis of Normal and Neoplastic Human Tissue. American Journal of Clinical Pathology, 92, 415-423.

[37] Baker, D.L., Molenaar, W.M., Trojanowski, J.Q., Evans, A.E., Ross, A.H., Rorke, L.B., Packer, R.J., Lee, V.M.Y. and Pleasure, D. (1991) Nerve Growth Factor Receptor Expression in Peripheral and Central Neuroectodermal Tumors, Other Pediatric Brain Tumors, and during Development of the Adrenal Gland. American Journal of Pathology, 139, 115-122. 
[38] Balik, V., Mirossay, P., Bohus, P., Sulla, I., Mirossay, L. and Sarissky, M. (2009) Flow Cytometry Analysis of Neural Differentiation Markers Expression in Human Glioblastomas May Predict Their Response to Chemotherapy. Cellular and Molecular Neurobiology, 29, 845-858. http://dx.doi.org/10.1007/s10571-009-9366-6

[39] Pleasure, S.J., Reddy, U.R., Venkatakrishnan, G., Roy, A.K., Chen, J., Ross, A.H., Trojanowski, J.Q., Pleasure, D.E. and Lee, V.M. (1990) Introduction of Nerve Growth Factor (NGF) Receptors into a Medulloblastoma Cell Line Results in Expression of High- and Low-Affinity NGF Receptors but Not NGF-Mediated Differentiation. Proceedings of the National Academy of Sciences of the United States of America, 87, 8496-8500. http://dx.doi.org/10.1073/pnas.87.21.8496

[40] Maecker, H.T., Todd, S.C. and Levy, S. (1997) The Tetraspanin Superfamily: Molecular Facilitators. FASEB Journal, 11, 428-442.

[41] Hemler, M.E. (2005) Tetraspanin Functions and Associated Microdomains. Nature Reviews Molecular Cell Biology, 6, 801-811. http://dx.doi.org/10.1038/nrm1736

[42] Mita, A.C., Mita, M.M., Nawrocki, S.T. and Giles, F.J. (2008) Survivin: Key Regulator of Mitosis and Apoptosis and Novel Target for Cancer Therapeutics. Clinical Cancer Research, 14, 5000-5005. http://dx.doi.org/10.1158/1078-0432.CCR-08-0746

[43] Pathi, S., Jutooru, I., Chadalapaka, G., Nair, V., Lee, S.O. and Safe, S. (2012) Aspirin Inhibits Colon Cancer Cell and Tumor Growth and Downregulates Specificity Protein (Sp) Transcription Factors. PLoS ONE, 7, e48208. http://dx.doi.org/10.1371/journal.pone.0048208 


\section{Supplemental}

Table 1. Prioritization and selection of candidate biomarkers from CRC cell secretomes.

\begin{tabular}{|c|c|c|c|c|c|c|c|}
\hline Category & Criteria $^{*}$ & Protein name & $\begin{array}{l}\text { Gene } \\
\text { symbol }\end{array}$ & Criterion 1 & Criterion 2 & Criterion 3 & Criterion 4 \\
\hline \multirow[t]{2}{*}{ A } & \multirow{2}{*}{$1+2$ or $1+3$} & $\begin{array}{l}\text { Tumor-associated calcium signal } \\
\text { transducer } 2 / \text { trophoblast cell surface } \\
\text { antigen } 2\end{array}$ & $\begin{array}{l}\text { TACSTD2/ } \\
\text { TROP2 }\end{array}$ & Yes & No & {$[1]-[6]$} & \\
\hline & & $\begin{array}{l}\text { Transmembrane } 9 \text { superfamily member } \\
2\end{array}$ & TM9SF2 & Yes & Yes & & \\
\hline \multirow{15}{*}{ B } & \multirow{15}{*}{$\begin{array}{l}1+4 \text { or } 2+3 \\
\quad \text { or } 2+4\end{array}$} & Tetraspanin-6 & TSPAN6 & No & Yes & & [7] [8] \\
\hline & & Bone marrow stromal antigen 2 & BST2 & No & Yes & {$[9]-[12]$} & \\
\hline & & $\begin{array}{l}\text { Tumor necrosis factor receptor superfa- } \\
\text { mily member } 16\end{array}$ & NGFR & No & Yes & {$[13]-[17]$} & \\
\hline & & Glia-activating factor & FGF9 & No & Yes & {$[18]-[22]$} & \\
\hline & & $\begin{array}{l}\text { Isoform } 3 \text { of Canalicular } \\
\text { multispecific organic anion } \\
\text { transporter } 2\end{array}$ & $\mathrm{ABCC}^{* *}$ & Yes & No & {$[23]-[27]$} & \\
\hline & & Cell surface A33 antigen & GPA33 & No & Yes & {$[28]-[32]$} & \\
\hline & & $\begin{array}{l}55 \mathrm{kDa} \text { erythrocyte membrane } \\
\text { protein }\end{array}$ & MPP1 & No & Yes & & {$[33]-[36]$} \\
\hline & & $142 \mathrm{kDa}$ protein & PCDH24 & No & Yes & [37] & \\
\hline & & $\begin{array}{l}\text { Isoform } 2 \text { of Ankyrin repeat-rich mem- } \\
\text { brane spanning protein }\end{array}$ & KIDINS220 & No & Yes & {$[38]$} & \\
\hline & & Flotillin 2 & FLOT2 & No & Yes & {$[39]-[41]$} & \\
\hline & & Trefoil factor 3 & TFF3 & No & Yes & {$[42]-[46]$} & \\
\hline & & Isoform long of Antigen KI-67 & MKI67 & No & Yes & {$[47]-[49]$} & \\
\hline & & $22 \mathrm{kDa}$ protein & TIMP2 & No & Yes & {$[50]-[53]$} & \\
\hline & & Claudin-3 & CLDN3 & No & Yes & {$[54]-[59]$} & \\
\hline & & Metallothionein-3 & МТ3 & No & Yes & {$[60]-[62]$} & \\
\hline \multirow{17}{*}{$\mathrm{C}$} & \multirow{17}{*}{2 or 3 or 4} & EPHB6 protein & EPHB6 & No & No & {$[63]-[67]$} & \\
\hline & & $\begin{array}{l}\text { Rho-related BTB } \\
\text { domain-containing protein } 3\end{array}$ & RHOBTB3 & No & Yes & & \\
\hline & & Galactoside 3 (4)-L-fucosyltransferase & FUT3 & No & No & {$[68]-[70]$} & \\
\hline & & Protein VAC14 homolog & VAC14 & No & Yes & & \\
\hline & & $\begin{array}{l}\text { Isoform } 1 \text { of TRAF2 and } \\
\text { NCK-interacting protein kinase }\end{array}$ & TNIK & No & Yes & & \\
\hline & & Isoform 3 of Misshapen-like kinase 1 & MINK1 & No & No & {$[71]-[73]$} & \\
\hline & & Protein-tyrosine kinase fyn isoform c & FYN & No & Yes & & \\
\hline & & $\begin{array}{l}\text { Isoform } 2 \text { of protein } \\
\text { phosphatase slingshot homolog } 3\end{array}$ & SSH3 & No & Yes & & \\
\hline & & Xylosyltransferase 1 & XYLT1 $1^{* * *}$ & Yes & Yes & & \\
\hline & & 70 kDa protein & SLC6A6 & No & Yes & & \\
\hline & & Protein APCDD1 & APCDD1 & No & Yes & & \\
\hline & & $\begin{array}{l}\text { Isoform CSBP1 of } \\
\text { Mitogen-activated protein kinase } 14\end{array}$ & MAPK14 & No & Yes & & \\
\hline & & Ephrin type-B receptor 3 & EPHB3 & No & Yes & & \\
\hline & & $\begin{array}{l}\text { Ataxia telangiectasia mutated protein } \\
\text { isoform } 2\end{array}$ & ATM & No & Yes & & \\
\hline & & Stromal cell-derived factor 2 & SDF2 & No & No & {$[74][75]$} & \\
\hline & & Perforin-1 & PRF1 & No & No & {$[76]$} & \\
\hline & & Inhibin beta B chain & INHBB & No & No & [77]-[79] & \\
\hline
\end{tabular}




\section{Continued}

\begin{tabular}{|c|c|c|c|c|c|c|c|}
\hline & & Coagulation factor XIII A chain & F13A1 & No & No & {$[80]-[82]$} & \\
\hline & & $\begin{array}{l}\text { Low-density lipoprotein receptor-related } \\
\text { protein } 4\end{array}$ & LRP4 & No & Yes & & \\
\hline & & CDC42 binding protein kinase alpha & CDC42BPA & No & No & [83] & \\
\hline & & $\begin{array}{l}\text { Isoform long of Glycylpeptide } \\
\text { N-tetradecanoyltransferase } 1\end{array}$ & NMT1 & No & Yes & & \\
\hline & & $\begin{array}{l}\text { Cell growth regulator with EF hand } \\
\text { domain protein } 1\end{array}$ & CGREF1 & No & Yes & & \\
\hline & & Isoform 1 of protein KIAA1199 & KIAA1199 & No & No & {$[84]-[85]$} & \\
\hline & & AP1B1 protein & AP1B1 & No & No & [86]-[89] & \\
\hline & & Ladinin 1 & LAD1 & No & Yes & & \\
\hline & & $\begin{array}{l}\text { Isoform } 1 \text { of von Willebrand factor A } \\
\text { domain-containing protein } 2\end{array}$ & VWA2 & No & No & {$[90]$} & \\
\hline & & $\begin{array}{l}\text { Isoform } 1 \text { of Transmembrane } \\
\text { protein } 16 \mathrm{~A}\end{array}$ & TMEM16A & No & No & [91] [92] & \\
\hline & & $\begin{array}{l}\text { Isoform } 2 \text { of Condensin-2 } \\
\text { complex subunit G2 }\end{array}$ & NCAPG2 & No & Yes & & \\
\hline & & Prostatic acid phosphatase & ACPP & No & Yes & & \\
\hline & & $9 \mathrm{kDa}$ protein & RPS27 & No & No & [93]-[96] & \\
\hline & & $\begin{array}{l}\text { Isoform } 2 \text { of General transcription factor } \\
\text { 3C polypeptide } 5\end{array}$ & GTF3C5 & No & No & [97] [98] & \\
\hline & & $\begin{array}{l}\text { Isoform } 2 \text { of Transmembrane and TPR } \\
\text { repeat-containing protein } 3\end{array}$ & TMTC3 & No & Yes & & \\
\hline & & Catenin, beta like 1 & CTNNBL1 & No & Yes & & \\
\hline $\mathrm{C}$ & 2 or 3 or 4 & $\begin{array}{l}\text { Ras GTPase-activating-like protein } \\
\text { IQGAP3 }\end{array}$ & IQGAP3 & No & No & [99] [100] & \\
\hline & & $\begin{array}{l}\text { Isoform } 1 \text { of PDZ } \\
\text { domain-containing protein } 11\end{array}$ & PDZD11 & No & Yes & & \\
\hline & & Lipocalin 2 & LCN2 & No & Yes & & \\
\hline & & $\begin{array}{l}\text { cDNA FLJ46245 fis, clone } \\
\text { TESTI4020596, highly similar to Homo } \\
\text { sapiens calpain } 5\end{array}$ & CAPN5 & No & No & {$[101][102]$} & \\
\hline & & Proliferating-cell nucleolar antigen p120 & NOL1 & No & No & [103]-[105] & \\
\hline & & $\begin{array}{l}\text { Isoform } 1 \text { of Pregnancy-specific } \\
\text { beta-1-glycoprotein } 11\end{array}$ & PSG11 & No & No & {$[106][108]$} & \\
\hline & & $\begin{array}{l}\text { Isoform } 1 \text { of Choline } \\
\text { transporter-like protein } 1\end{array}$ & SLC44A1 & No & No & [109] & \\
\hline & & Phosphoglycerate mutase 2 & PGAM2 & No & No & [110] [111] & \\
\hline & & Isoform A of Nucleoporin SEH1-like & SEH1L & No & Yes & & \\
\hline & & Fibroblast growth factor 19 & FGF19 & No & No & [112] [113] & \\
\hline & & $\begin{array}{l}\text { Isoform } 2 \text { of Chloride intracellular } \\
\text { channel protein } 5\end{array}$ & CLIC5 & No & No & [114] & \\
\hline & & $36 \mathrm{kDa}$ protein & MFNG & No & No & & [115] \\
\hline & & $\begin{array}{l}\text { Eukaryotic translation initiation factor } \\
1 \mathrm{~A}, \mathrm{Y} \text {-chromosomal }\end{array}$ & EIF1AY & No & Yes & & \\
\hline & & Calcium and integrin-binding protein 1 & CIB1 & No & Yes & & \\
\hline & & Neutral amino acid transporter A & SLC1A4 & No & Yes & & \\
\hline & & $\begin{array}{l}\text { Receptor-type tyrosine-protein } \\
\text { phosphatase epsilon precursor }\end{array}$ & PTPRE & No & Yes & & \\
\hline
\end{tabular}

${ }^{*}$ Criteria: 1) Proteins detected in the high-confidence human plasma proteome reference set established in 2011 [States et al., 2006]

(http://www.hupo.org). 2) Proteins overexpressed in CRC tissue specimens in the Human Protein Atlas (HPA) dataset [Bjorling et al., 2008] (http://www.proteinatlas.org). 3) Proteins up-regulated in CRC in published references. 4) Functions as secreted proteins, or involving in apoptosis/signal transduction. ${ }^{* *}$ ABCC3 was set in category B due to previous literature lacking positive association in CRC. ${ }^{* * *}$ XYLT1 was set in category $\mathrm{C}$ because it is an enzyme which was not a favorable candidate for cancer biomarker. 


\section{References}

[1] Wang, J., Day, R., Dong, Y., Weintraub, S.J. and Michel, L. (2008) Identification of Trop-2 as an Oncogene and an Attractive Therapeutic Target in Colon Cancers. Molecular Cancer Therapeutics, 7, 280-285. http://dx.doi.org/10.1158/1535-7163.MCT-07-2003

[2] Ohmachi, T., Tanaka, F., Mimori, K., Inoue, H., Yanaga, K. and Mori, M. (2006) Clinical Significance of TROP2 Expression in Colorectal Cancer. Clinical Cancer Research, 12, 3057-3063. http://dx.doi.org/10.1158/1078-0432.CCR-05-1961

[3] Santin, A.D., Zhan, F., Bellone, S., Palmieri, M., Cane, S., Bignotti, E., Anfossi, S., Gokden, M., Dunn, D., Roman, J.J., O’Brien, T.J., Tian, E., Cannon, M.J., Shaughnessy Jr., J. and Pecorelli, S. (2004) Gene Expression Profiles in Primary Ovarian Serous Papillary Tumors and Normal Ovarian Epithelium: Identification of Candidate Molecular Markers for Ovarian Cancer Diagnosis and Therapy. International Journal of Cancer, 112, 14-25. http://dx.doi.org/10.1002/ijc.20408

[4] Huang, H., Groth, J., Sossey-Alaoui, K., Hawthorn, L., Beall, S. and Geradts, J. (2005) Aberrant Expression of Novel and Previously Described Cell Membrane Markers in Human Breast Cancer Cell Lines and Tumors. Clinical Cancer Research, 11, 4357-4364. http://dx.doi.org/10.1158/1078-0432.CCR-04-2107

[5] Fang, Y.J., Lu, Z.H., Wang, G.Q., Pan, Z.Z., Zhou, Z.W., Yun, J.P., Zhang, M.F. and Wan, D.S. (2009) Elevated Expressions of MMP7, TROP2, and Survivin Are Associated with Survival, Disease Recurrence, and Liver Metastasis of Colon Cancer. International Journal of Colorectal Disease, 24, 875-884. http://dx.doi.org/10.1007/s00384-009-0725-z

[6] Fong, D., Moser, P., Krammel, C., Gostner, J.M., Margreiter, R., Mitterer, M., Gastl, G. and Spizzo, G. (2008) High Expression of TROP2 Correlates with Poor Prognosis in Pancreatic Cancer. British Journal of Cancer, 99, 1290-1295. http://dx.doi.org/10.1038/sj.bjc.6604677

[7] Maecker, H.T., Todd, S.C. and Levy, S. (1997) The Tetraspanin Superfamily: Molecular Facilitators. FASEB Journal, 11, 428-442.

[8] Hemler, M.E. (2005) Tetraspanin Functions and Associated Microdomains. Nature Reviews Molecular Cell Biology, 6, 801-811. http://dx.doi.org/10.1038/nrm1736

[9] Cai, D., Cao, J., Li, Z., Zheng, X., Yao, Y., Li, W.L. and Yuan, Z.Q. (2009) Up-Regulation of Bone Marrow Stromal Protein 2 (BST2) in Breast Cancer with Bone Metastasis. BMC Cancer, 9, 102. http://dx.doi.org/10.1186/1471-2407-9-102

[10] Rew, S.B., Peggs, K., Sanjuan, I., Pizzey, A.R., Koishihara, Y., Kawai, S., Kosaka, M., Ozaki, S., Chain, B. and Yong, K.L. (2005) Generation of Potent Antitumor CTL from Patients with Multiple Myeloma Directed against HM1.24. Clinical Cancer Research, 11, 3377-3384. http://dx.doi.org/10.1158/1078-0432.CCR-04-0650

[11] Jalili, A., Ozaki, S., Hara, T., Shibata, H., Hashimoto, T., Abe, M., Nishioka, Y. and Matsumoto, T. (2005) Induction of HM1.24 Peptide-Specific Cytotoxic T Lymphocytes by Using Peripheral-Blood Stem-Cell Harvests in Patients with Multiple Myeloma. Blood, 106, 3538-3545. http://dx.doi.org/10.1182/blood-2005-04-1438

[12] Ozaki, S., Kosaka, M., Wakatsuki, S., Abe, M., Koishihara, Y. and Matsumoto, T. (1997) Immunotherapy of Multiple Myeloma with a Monoclonal Antibody Directed against a Plasma Cell-Specific Antigen, HM1.24. Blood, 90, 31793186.

[13] Lofton-Day, C., Model, F., Devos, T., Tetzner, R., Distler, J., Schuster, M., Song, X., Lesche, R., Liebenberg, V., Ebert, M., Molnar, B., Grutzmann, R., Pilarsky, C. and Sledziewski, A. (2008) DNA Methylation Biomarkers for BloodBased Colorectal Cancer Screening. Clinical Chemistry, 54, 414-423. http://dx.doi.org/10.1373/clinchem.2007.095992

[14] Reis-Filho, J.S., Steele, D., Di Palma, S., Jones, R.L., Savage, K., James, M., Milanezi, F., Schmitt, F.C. and Ashworth, A. (2006) Distribution and Significance of Nerve Growth Factor Receptor (NGFR/P75 ${ }^{\mathrm{NTR}}$ ) in Normal, Benign and Malignant Breast Tissue. Modern Pathology, 19, 307-319. http://dx.doi.org/10.1038/modpathol.3800542

[15] Borrello, M.G., Bongarzone, I., Pierotti, M.A., Luksch, R., Gasparini, M., Collini, P., Pilotti, S., Rizzetti, M.G., Mondellini, P., De Bernardi, B., et al. (1993) trk and ret Proto-Oncogene Expression in Human Neuroblastoma Specimens: High Frequency of trk Expression in Non-Advanced Stages. International Journal of Cancer, 54, 540-545. http://dx.doi.org/10.1002/ijc.2910540404

[16] Baker, D.L., Reddy, U.R., Pleasure, D., Thorpe, C.L., Evans, A.E., Cohen, P.S. and Ross, A.H. (1989) Analysis of Nerve Growth Factor Receptor Expression in Human Neuroblastoma and Neuroepithelioma Cell Lines. Cancer Research, 49, 4142-4146.

[17] Wang, W., Zhao, H., Zhang, S., Kang, E., Chen, Y., Ni, C., Zhang, S. and Zhu, M. (2009) Patterns of Expression and Function of the P75 ${ }^{\mathrm{NGFR}}$ Protein in Pancreatic Cancer Cells and Tumours. European Journal of Surgical Oncology, 35, 826-832. http://dx.doi.org/10.1016/j.ejso.2008.10.013

[18] Hendrix, N.D., Wu, R., Kuick, R., Schwartz, D.R., Fearon, E.R. and Cho, K.R. (2006) Fibroblast Growth Factor 9 Has 
Oncogenic Activity and Is a Downstream Target of Wnt Signaling in Ovarian Endometrioid Adenocarcinomas. Cancer Research, 66, 1354-1362. http://dx.doi.org/10.1158/0008-5472.CAN-05-3694

[19] Todo, T., Kondo, T., Kirino, T., Asai, A., Adams, E.F., Nakamura, S., Ikeda, K. and Kurokawa, T. (1998) Expression and Growth Stimulatory Effect of Fibroblast Growth Factor 9 in Human Brain Tumors. Neurosurgery, 43, 337-346. http://dx.doi.org/10.1097/00006123-199808000-00098

[20] Penault-Llorca, F., Bertucci, F., Adelaide, J., Parc, P., Coulier, F., Jacquemier, J., Birnbaum, D. and Delapeyriere, O. (1995) Expression of $f g f$ and $f g f$ Receptor Genes in Human Breast Cancer. International Journal of Cancer, 61, 170176. http://dx.doi.org/10.1002/ijc.2910610205

[21] Wang, C.K., Chang, H., Chen, P.H., Chang, J.T., Kuo, Y.C., Ko, J.L. and Lin, P. (2009) Aryl Hydrocarbon Receptor Activation and Overexpression Upregulated Fibroblast Growth Factor-9 in Human Lung Adenocarcinomas. International Journal of Cancer, 125, 807-815. http://dx.doi.org/10.1002/ijc.24348

[22] Mulder, D.J., Pacheco, I., Hurlbut, D.J., Mak, N., Furuta, G.T., Macleod, R.J. and Justinich, C.J. (2009) FGF9-Induced Proliferative Response to Eosinophilic Inflammation in Oesophagitis. Gut, 58, 166-173. http://dx.doi.org/10.1136/gut.2008.157628

[23] Theile, D., Grebhardt, S., Haefeli, W.E. and Weiss, J. (2009) Involvement of Drug Transporters in the Synergistic Action of FOLFOX Combination Chemotherapy. Biochemical Pharmacology, 78, 1366-1373. http://dx.doi.org/10.1016/j.bcp.2009.07.006

[24] Liu, Y., Peng, H. and Zhang, J.T. (2005) Expression Profiling of ABC Transporters in a Drug-Resistant Breast Cancer Cell Line Using AmpArray. Molecular Pharmacology, 68, 430-438.

[25] Nies, A.T., Konig, J., Pfannschmidt, M., Klar, E., Hofmann, W.J. and Keppler, D. (2001) Expression of the Multidrug Resistance Proteins MRP2 and MRP3 in Human Hepatocellular Carcinoma. International Journal of Cancer, 94, 492499. http://dx.doi.org/10.1002/ijc.1498

[26] Narayan, G., Bourdon, V., Chaganti, S., Arias-Pulido, H., Nandula, S.V., Rao, P.H., Gissmann, L., Durst, M., Schneider, A., Pothuri, B., Mansukhani, M., Basso, K., Chaganti, R.S. and Murty, V.V. (2007) Gene Dosage Alterations Revealed by cDNA Microarray Analysis in Cervical Cancer: Identification of Candidate Amplified and Overexpressed Genes. Genes, Chromosomes and Cancer, 46, 373-384. http://dx.doi.org/10.1002/gcc.20418

[27] Bronger, H., Konig, J., Kopplow, K., Steiner, H.H., Ahmadi, R., Herold-Mende, C., Keppler, D. and Nies, A.T. (2005) ABCC Drug Efflux Pumps and Organic Anion Uptake Transporters in Human Gliomas and the Blood-Tumor Barrier. Cancer Research, 65, 11419-11428. http://dx.doi.org/10.1158/0008-5472.CAN-05-1271

[28] Moritz, R.L., Ritter, G., Catimel, B., Cohen, L.S., Welt, S., Old, L.J., Burgess, A.W., Nice, E.C. and Simpson, R.J. (1998) Micro-Sequencing Strategies for the Human A33 Antigen, a Novel Surface Glycoprotein of Human Gastrointestinal Epithelium. Journal of Chromatography A, 798, 91-101. http://dx.doi.org/10.1016/S0021-9673(97)01031-5

[29] Solmi, R., De Sanctis, P., Zucchini, C., Ugolini, G., Rosati, G., Del Governatore, M., Coppola, D., Yeatman, T.J., Lenzi, L., Caira, A., Zanotti, S., Taffurelli, M., Carinci, P., Valvassori, L. and Strippoli, P. (2004) Search for EpithelialSpecific mRNAs in Peripheral Blood of Patients with Colon Cancer by RT-PCR. International Journal of Oncology, 25, 1049-1056.

[30] Wong, N.A., Warren, B.F., Piris, J., Maynard, N., Marshall, R. and Bodmer, W.F. (2006) EpCAM and gpA33 Are Markers of Barrett's Metaplasia. Journal of Clinical Pathology, 59, 260-263. http://dx.doi.org/10.1136/jcp.2005.027474

[31] Rageul, J., Mottier, S., Jarry, A., Shah, Y., Theoleyre, S., Masson, D., Gonzalez, F.J., Laboisse, C.L. and Denis, M.G. (2009) KLF4-Dependent, PPAR $\gamma$-Induced Expression of GPA33 in Colon Cancer Cell Lines. International Journal of Cancer, 125, 2802-2809. http://dx.doi.org/10.1002/ijc.24683

[32] Cafferata, E.G., Maccio, D.R., Lopez, M.V., Viale, D.L., Carbone, C., Mazzolini, G. and Podhajcer, O.L. (2009) A Novel A33 Promoter-Based Conditionally Replicative Adenovirus Suppresses Tumor Growth and Eradicates Hepatic Metastases in Human Colon Cancer Models. Clinical Cancer Research, 15, 3037-3049. http://dx.doi.org/10.1158/1078-0432.CCR-08-1161

[33] Marfatia, S.M., Leu, R.A., Branton, D. and Chishti, A.H. (1995) Identification of the Protein 4.1 Binding Interface on Glycophorin C and p55, a Homologue of the Drosophila discs-large Tumor Suppressor Protein. Journal of Biological Chemistry, 270, 715-719. http://dx.doi.org/10.1074/jbc.270.2.715

[34] Kim, A.C., Metzenberg, A.B., Sahr, K.E., Marfatia, S.M. and Chishti, A.H. (1996) Complete Genomic Organization of the Human Erythroid p55 Gene (MPP1), a Membrane-Associated Guanylate Kinase Homologue. Genomics, 31, 223229. http://dx.doi.org/10.1006/geno.1996.0035

[35] Ruff, P., Speicher, D.W. and Husain-Chishti, A. (1991) Molecular Identification of a Major Palmitoylated Erythrocyte Membrane Protein Containing the Src Homology 3 Motif. Proceedings of the National Academy of Sciences of the United States of America, 88, 6595-6599. http://dx.doi.org/10.1073/pnas.88.15.6595 
[36] Marfatia, S.M., Morais-Cabral, J.H., Kim, A.C., Byron, O. and Chishti, A.H. (1997) The PDZ Domain of Human Erythrocyte p55 Mediates Its Binding to the Cytoplasmic Carboxyl Terminus of Glycophorin C. Analysis of the Binding Interface by in Vitro Mutagenesis. Journal of Biological Chemistry, 272, 24191-24197. http://dx.doi.org/10.1074/jbc.272.39.24191

[37] Ose, R., Yanagawa, T., Ikeda, S., Ohara, O. and Koga, H. (2009) PCDH24-Induced Contact Inhibition Involves Downregulation of $\beta$-Catenin Signaling. Molecular Oncology, 3, 54-66. http://dx.doi.org/10.1016/j.molonc.2008.10.005

[38] Liao, Y.H., Hsu, S.M. and Huang, P.H. (2007) ARMS Depletion Facilitates UV Irradiation Induced Apoptotic Cell Death in Melanoma. Cancer Research, 67, 11547-11556. http://dx.doi.org/10.1158/0008-5472.CAN-07-1930

[39] Hazarika, P., Mccarty, M.F., Prieto, V.G., George, S., Babu, D., Koul, D., Bar-Eli, M. and Duvic, M. (2004) Up-Regulation of Flotillin-2 Is Associated with Melanoma Progression and Modulates Expression of the Thrombin Receptor Protease Activated Receptor 1. Cancer Research, 64, 7361-7369. http://dx.doi.org/10.1158/0008-5472.CAN-04-0823

[40] Doherty, S.D., Prieto, V.G., George, S., Hazarika, P. and Duvic, M. (2006) High Flotillin-2 Expression Is Associated with Lymph Node Metastasis and Breslow Depth in Melanoma. Melanoma Research, 16, 461-463. http://dx.doi.org/10.1097/01.cmr.0000222592.75858.20

[41] Yang, X.Y., Ren, C.P., Wang, L., Li, H., Jiang, C.J., Zhang, H.B., Zhao, M. and Yao, K.T. (2005) Identification of Differentially Expressed Genes in Metastatic and Non-Metastatic Nasopharyngeal Carcinoma Cells by Suppression Subtractive Hybridization. Cellular Oncology, 27, 215-223.

[42] Babyatsky, M., Lin, J., Yio, X., Chen, A., Zhang, J.Y., Zheng, Y., Twyman, C., Bao, X., Schwartz, M., Thung, S., Lawrence Werther, J. and Itzkowitz, S. (2009) Trefoil Factor-3 Expression in Human Colon Cancer Liver Metastasis. Clinical \& Experimental Metastasis, 26, 143-151. http://dx.doi.org/10.1007/s10585-008-9224-9

[43] Leung, W.K., Yu, J., Chan, F.K., To, K.F., Chan, M.W., Ebert, M.P., Ng, E.K., Chung, S.C., Malfertheiner, P. and Sung, J.J. (2002) Expression of Trefoil Peptides (TFF1, TFF2, and TFF3) in Gastric Carcinomas, Intestinal Metaplasia, and Non-Neoplastic Gastric Tissues. Journal of Pathology, 197, 582-588. http://dx.doi.org/10.1002/path.1147

[44] Poulsom, R., Hanby, A.M., Lalani, E.N., Hauser, F., Hoffmann, W. and Stamp, G.W. (1997) Intestinal Trefoil Factor (TFF 3) and Ps2 (TFF 1), But Not Spasmolytic Polypeptide (TFF 2) mRNAs Are Co-Expressed in Normal, Hyperplastic, and Neoplastic Human Breast Epithelium. Journal of Pathology, 183, 30-38. http://dx.doi.org/10.1002/(SICI)1096-9896(199709)183:1<30::AID-PATH1085>3.0.CO;2-K

[45] Van Baal, J.W., Milana, F., Rygiel, A.M., Sondermeijer, C.M., Spek, C.A., Bergman, J.J., Peppelenbosch, M.P. and Krishnadath, K.K. (2008) A Comparative Analysis by SAGE of Gene Expression Profiles of Esophageal Adenocarcinoma and Esophageal Squamous Cell Carcinoma. Cellular Oncology, 30, 63-75.

[46] Vestergaard, E.M., Borre, M., Poulsen, S.S., Nexo, E. and Tørring, N. (2006) Plasma Levels of Trefoil Factors Are Increased in Patients with Advanced Prostate Cancer. Clinical Cancer Research, 12, 807-812. http://dx.doi.org/10.1158/1078-0432.CCR-05-1545

[47] Hanna-Morris, A., Badvie, S., Cohen, P., Mccullough, T., Andreyev, H.J. and Allen-Mersh, T.G. (2009) Minichromosome Maintenance Protein 2 (MCM2) Is a Stronger Discriminator of Increased Proliferation in Mucosa Adjacent to Colorectal Cancer than Ki-67. Journal of Clinical Pathology, 62, 325-330. http://dx.doi.org/10.1136/jcp.2007.054643

[48] Dziegiel, P., Forgacz, J., Suder, E., Surowiak, P., Kornafel, J. and Zabel, M. (2003) Prognostic Significance of Metallothionein Expression in Correlation with Ki-67 Expression in Adenocarcinomas of Large Intestine. Histology and Histopathology, 18, 401-407.

[49] Allegra, C.J., Paik, S., Colangelo, L.H., Parr, A.L., Kirsch, I., Kim, G., Klein, P., Johnston, P.G., Wolmark, N. and Wieand, H.S. (2003) Prognostic Value of Thymidylate Synthase, Ki-67, and p53 in Patients with Dukes' B and C Colon Cancer: A National Cancer Institute-National Surgical Adjuvant Breast and Bowel Project Collaborative Study. Journal of Clinical Oncology, 21, 241-250. http://dx.doi.org/10.1200/JCO.2003.05.044

[50] Smith, M.J., Culhane, A.C., Donovan, M., Coffey, J.C., Barry, B.D., Kelly, M.A., Higgins, D.G., Wang, J.H., Kirwan, W.O., Cotter, T.G. and Redmond, H.P. (2009) Analysis of Differential Gene Expression in Colorectal Cancer and Stroma Using Fluorescence-Activated Cell Sorting Purification. British Journal of Cancer, 100, 1452-1464. http://dx.doi.org/10.1038/sj.bjc.6604931

[51] Theret, N., Musso, O., Campion, J.P., Turlin, B., Loreal, O., L’Helgoualc’h, A. and Clement, B. (1997) Overexpression of Matrix Metalloproteinase-2 and Tissue Inhibitor of Matrix Metalloproteinase-2 in Liver from Patients with Gastrointestinal Adenocarcinoma and No Detectable Metastasis. International Journal of Cancer, 74, 426-432. http://dx.doi.org/10.1002/(SICI)1097-0215(19970822)74:4<426::AID-IJC11>3.0.CO;2-7

[52] Pritchard, S.C., Nicolson, M.C., Lloret, C., Mckay, J.A., Ross, V.G., Kerr, K.M., Murray, G.I. and Mcleod, H.L. (2001) Expression of Matrix Metalloproteinases 1, 2, 9 and Their Tissue Inhibitors in Stage II Non-Small Cell Lung Cancer: Implications for MMP Inhibition Therapy. Oncology Reports, 8, 421-424.

[53] Musso, O., Theret, N., Campion, J.P., Turlin, B., Milani, S., Grappone, C. and Clement, B. (1997) In Situ Detection of Matrix Metalloproteinase-2 (MMP2) and the Metalloproteinase Inhibitor TIMP2 Transcripts in Human Primary Hepa- 
tocellular Carcinoma and in Liver Metastasis. Journal of Hepatology, 26, 593-605. http://dx.doi.org/10.1016/S0168-8278(97)80425-4

[54] Mees, S.T., Mennigen, R., Spieker, T., Rijcken, E., Senninger, N., Haier, J. and Bruewer, M. (2009) Expression of Tight and Adherens Junction Proteins in Ulcerative Colitis Associated Colorectal Carcinoma: Upregulation of Claudin-1, Claudin-3, Claudin-4, and Beta-Catenin. International Journal of Colorectal Disease, 24, 361-368. http://dx.doi.org/10.1007/s00384-009-0653-y

[55] Hewitt, K.J., Agarwal, R. and Morin, P.J. (2006) The Claudin Gene Family: Expression in Normal and Neoplastic Tissues. BMC Cancer, 6, 186. http://dx.doi.org/10.1186/1471-2407-6-186

[56] De Oliveira, S.S., De Oliveira, I.M., De Souza, W. and Morgado-Diaz, J.A. (2005) Claudins Upregulation in Human Colorectal Cancer. FEBS Letters, 579, 6179-6185. http://dx.doi.org/10.1016/j.febslet.2005.09.091

[57] Huang, Y.H., Bao, Y., Peng, W., Goldberg, M., Love, K., Bumcrot, D.A., Cole, G., Langer, R., Anderson, D.G. and Sawicki, J.A. (2009) Claudin-3 Gene Silencing with siRNA Suppresses Ovarian Tumor Growth and Metastasis. Proceedings of the National Academy of Sciences of the United States of America, 106, 3426-3430. http://dx.doi.org/10.1073/pnas.0813348106

[58] Soini, Y. (2004) Claudins 2, 3, 4, and 5 in Paget’s Disease and Breast Carcinoma. Human Pathology, 35, $1531-1536$. http://dx.doi.org/10.1016/j.humpath.2004.09.015

[59] Santin, A.D., Zhan, F., Cane’, S., Bellone, S., Palmieri, M., Thomas, M., Burnett, A., Roman, J.J., Cannon, M.J., Shaughnessy Jr., J. and Pecorelli, S. (2005) Gene Expression Fingerprint of Uterine Serous Papillary Carcinoma: Identification of Novel Molecular Markers for Uterine Serous Cancer Diagnosis and Therapy. British Journal of Cancer, 92, 1561-1573. http://dx.doi.org/10.1038/sj.bjc.6602480

[60] Tian, Z.Q., Wang, X.L. and Wu, W. (2008) Expression of Metallothionein-3 in Esophageal Cancer and Its Correlations to Expression of Metallothionein-1 and -2. Ai Zheng, 27, 160-164. (Chinese)

[61] Deng, D., El-Rifai, W., Ji, J., Zhu, B., Trampont, P., Li, J., Smith, M.F. and Powel, S.M. (2003) Hypermethylation of Metallothionein-3 CpG Island in Gastric Carcinoma. Carcinogenesis, 24, 25-29. http://dx.doi.org/10.1093/carcin/24.1.25

[62] Hoey, J.G., Garrett, S.H., Sens, M.A., Todd, J.H. and Sens, D.A. (1997) Expression of MT-3 mRNA in Human Kidney, Proximal Tubule Cell Cultures, and Renal Cell Carcinoma. Toxicology Letters, 92, 149-160. http://dx.doi.org/10.1016/S0378-4274(97)00049-0

[63] Hafner, C., Schmitz, G., Meyer, S., Bataille, F., Hau, P., Langmann, T., Dietmaier, W., Landthaler, M. and Vogt, T. (2004) Differential Gene Expression of Eph Receptors and Ephrins in Benign Human Tissues and Cancers. Clinical Chemistry, 50, 490-499. http://dx.doi.org/10.1373/clinchem.2003.026849

[64] Jin, M., Komohara, Y., Shichijo, S., Yamanaka, R., Nikawa, J., Itoh, K. and Yamada, A. (2008) Erythropoietin-Producing Hepatocyte B6 Variant-Derived Peptides with the Ability to Induce Glioma-Reactive Cytotoxic T Lymphocytes in Human Leukocyte Antigen-A2 ${ }^{+}$Glioma Patients. Cancer Science, 99, 1656-1662. http://dx.doi.org/10.1111/j.1349-7006.2008.00866.X

[65] Jin, M., Komohara, Y., Shichijo, S., Harada, M., Yamanaka, R., Miyamoto, S., Nikawa, J., Itoh, K. and Yamada, A. (2008) Identification of EphB6 Variant-Derived Epitope Peptides Recognized by Cytotoxic T-Lymphocytes from HLA-A24+ Malignant Glioma Patients. Oncology Reports, 19, 1277-1283.

[66] Muller-Tidow, C., Schwable, J., Steffen, B., Tidow, N., Brandt, B., Becker, K., Schulze-Bahr, E., Halfter, H., Vogt, U., Metzger, R., Schneider, P.M., Buchner, T., Brandts, C., Berdel, W.E. and Serve, H. (2004) High-Throughput Analysis of Genome-Wide Receptor Tyrosine Kinase Expression in Human Cancers Identifies Potential Novel Drug Targets. Clinical Cancer Research, 10, 1241-1249. http://dx.doi.org/10.1158/1078-0432.CCR-0954-03

[67] Fox, B.P. and Kandpal, R.P. (2009) EphB6 Receptor Significantly Alters Invasiveness and Other Phenotypic Characteristics of Human Breast Carcinoma Cells. Oncogene, 28, 1706-1713. http://dx.doi.org/10.1038/onc.2009.18

[68] Weston, B.W., Hiller, K.M., Mayben, J.P., Manousos, G.A., Bendt, K.M., Liu, R. and Cusack Jr., J.C. (1999) Expression of Human Alpha(1,3)fucosyltransferase Antisense Sequences Inhibits Selectin-Mediated Adhesion and Liver Metastasis of Colon Carcinoma Cells. Cancer Research, 59, 2127-2135.

[69] Escrevente, C., Machado, E., Brito, C., Reis, C.A., Stoeck, A., Runz, S., Marme, A., Altevogt, P. and Costa, J. (2006) Different Expression Levels of Alpha3/4 Fucosyltransferases and Lewis Determinants in Ovarian Carcinoma Tissues and Cell Lines. International Journal of Oncology, 29, 557-566.

[70] Lopez-Ferrer, A., De Bolos, C., Barranco, C., Garrido, M., Isern, J., Carlstedt, I., Reis, C.A., Torrado, J. and Real, F.X. (2000) Role of Fucosyltransferases in the Association between Apomucin and Lewis Antigen Expression in Normal and Malignant Gastric Epithelium. Gut, 47, 349-356. http://dx.doi.org/10.1136/gut.47.3.349

[71] Dan, I., Watanabe, N.M., Kobayashi, T., Yamashita-Suzuki, K., Fukagaya, Y., Kajikawa, E., Kimura, W.K., Nakashima, T.M., Matsumoto, K., Ninomiya-Tsuji, J. and Kusumi, A. (2000) Molecular Cloning of MINK, a Novel Member 
of Mammalian GCK Family Kinases, Which Is Up-Regulated during Postnatal Mouse Cerebral Development. FEBS Letters, 469, 19-23. http://dx.doi.org/10.1016/S0014-5793(00)01247-3

[72] Hu, Y., Leo, C., Yu, S., Huang, B.C., Wang, H., Shen, M., Luo, Y., Daniel-Issakani, S., Payan, D.G. and Xu, X. (2004) Identification and Functional Characterization of a Novel Human Misshapen/Nck Interacting Kinase-Related Kinase, Hmink Beta. Journal of Biological Chemistry, 279, 54387-54397.

[73] Daulat, A.M., Luu, O., Sing, A., Zhang, L., Wrana, J.L., Mcneill, H., Winklbauer, R. and Angers, S. (2012) Mink1 Regulates $\beta$-Catenin-Independent Wnt Signaling via Prickle Phosphorylation. Molecular and Cellular Biology, 32, 173-185.

[74] Kang, H., Escudero-Esparza, A., Douglas-Jones, A., Mansel, R.E. and Jiang, W.G. (2009) Transcript Analyses of Stromal Cell Derived Factors (SDFs): SDF-2, SDF-4 and SDF-5 Reveal a Different Pattern of Expression and Prognostic Association in Human Breast Cancer. International Journal of Oncology, 35, 205-211.

[75] Vendrell, E., Ribas, M., Valls, J., Sole, X., Grau, M., Moreno, V., Capella, G. and Peinado, M.A. (2007) Genomic and Transcriptomic Prognostic Factors in R0 Dukes B and C Colorectal Cancer Patients. International Journal of Oncology, 30, 1099-1107.

[76] Leger-Ravet, M.B., Mathiot, C., Portier, A., Brandely, M., Galanaud, P., Fridman, W.H. and Emilie, D. (1994) Increased Expression of Perforin and Granzyme B Genes in Patients with Metastatic Melanoma Treated with Recombinant Interleukin-2. Cancer Immunology, Immunotherapy, 39, 53-58. http://dx.doi.org/10.1007/BF01517181

[77] Mayor, R., Casadome, L., Azuara, D., Moreno, V., Clark, S.J., Capella, G. and Peinado, M.A. (2009) Long-Range Epigenetic Silencing at 2q14.2 Affects Most Human Colorectal Cancers and May Have Application as a Non-Invasive Biomarker of Disease. British Journal of Cancer, 100, 1534-1539. http://dx.doi.org/10.1038/sj.bjc.6605045

[78] Mylonas, I., Jeschke, U., Shabani, N., Kuhn, C., Friese, K. and Gerber, B. (2005) Inhibin/Activin Subunits (Inhibin-Alpha, -BetaA and -BetaB) Are Differentially Expressed in Human Breast Cancer and Their Metastasis. Oncology Reports, 13, 81-88.

[79] Boelens, M.C., Van Den Berg, A., Fehrmann, R.S., Geerlings, M., De Jong, W.K., Te Meerman, G.J., Sietsma, H., Timens, W., Postma, D.S. and Groen, H.J. (2009) Current Smoking-Specific Gene Expression Signature in Normal Bronchial Epithelium Is Enhanced in Squamous Cell Lung Cancer. Journal of Pathology, 218, 182-191. http://dx.doi.org/10.1002/path.2520

[80] Wojtukiewicz, M.Z., Zacharski, L.R., Memoli, V.A., Kisiel, W., Kudryk, B.J., Rousseau, S.M. and Stump, D.C. (1989) Indirect Activation of Blood Coagulation in Colon Cancer. Thrombosis and Haemostasis, 62, 1062-1066.

[81] D’Argenio, G., Calvani, M., Della Valle, N., Cosenza, V., Di Matteo, G., Giorgio, P., Margarucci, S., Petillo, O., Jori, F.P., Galderisi, U. and Peluso, G. (2005) Differential Expression of Multiple Transglutaminases in Human Colon: Impaired Keratinocyte Transglutaminase Expression in Ulcerative Colitis. Gut, 54, 496-502. http://dx.doi.org/10.1136/gut.2004.049411

[82] Morrissey, C., True, L.D., Roudier, M.P., Coleman, I.M., Hawley, S., Nelson, P.S., Coleman, R., Wang, Y.C., Corey, E., Lange, P.H., Higano, C.S. and Vessella, R.L. (2008) Differential Expression of Angiogenesis Associated Genes in Prostate Cancer Bone, Liver and Lymph Node Metastases. Clinical \& Experimental Metastasis, 25, 377-388. http://dx.doi.org/10.1007/s10585-007-9116-4

[83] Bourguignon, L.Y., Gilad, E., Rothman, K. and Peyrollier, K. (2005) Hyaluronan-CD44 Interaction with IQGAP1 Promotes Cdc42 and ERK Signaling, Leading to Actin Binding, Elk-1/Estrogen Receptor Transcriptional Activation, and Ovarian Cancer Progression. Journal of Biological Chemistry, 280, 11961-11972. http://dx.doi.org/10.1074/jbc.M411985200

[84] Matsuzaki, S., Tanaka, F., Mimori, K., Tahara, K., Inoue, H. and Mori, M. (2009) Clinicopathologic Significance of KIAA1199 Overexpression in Human Gastric Cancer. Annals of Surgical Oncology, 16, 2042-2051. http://dx.doi.org/10.1245/s10434-009-0469-6

[85] Sabates-Bellver, J., Van Der Flier, L.G., De Palo, M., Cattaneo, E., Maake, C., Rehrauer, H., Laczko, E., Kurowski, M.A., Bujnicki, J.M., Menigatti, M., Luz, J., Ranalli, T.V., Gomes, V., Pastorelli, A., Faggiani, R., Anti, M., Jiricny, J., Clevers, H. and Marra, G. (2007) Transcriptome Profile of Human Colorectal Adenomas. Molecular Cancer Research, 5, 1263-1275. http://dx.doi.org/10.1158/1541-7786.MCR-07-0267

[86] Lai, M.M., Luo, H.R., Burnett, P.E., Hong, J.J. and Snyder, S.H. (2000) The Calcineurin-Binding Protein Cain Is a Negative Regulator of Synaptic Vesicle Endocytosis. Journal of Biological Chemistry, 275, 34017-34020. http://dx.doi.org/10.1074/jbc.C000429200

[87] Doray, B. and Kornfeld, S. (2001) $\gamma$ Subunit of the AP-1 Adaptor Complex Binds Clathrin: Implications for Cooperative Binding in Coated Vesicle Assembly. Molecular Biology of the Cell, 12, 1925-1935. http://dx.doi.org/10.1091/mbc.12.7.1925

[88] Kang, R.S. and Fölsch, H. (2011) ARH Cooperates with AP-1B in the Exocytosis of LDLR in Polarized Epithelial Cells. Journal of Cell Biology, 193, 51-60. http://dx.doi.org/10.1083/jcb.201012121 
[89] Mills, I.G., Praefcke, G.J., Vallis, Y., Peter, B.J., Olesen, L.E., Gallop, J.L., Butler, P.J., Evans, P.R. and Mcmahon, H.T. (2003) EpsinR: An AP1/Clathrin Interacting Protein Involved in Vesicle Trafficking. Journal of Cell Biology, 160, 213-222. http://dx.doi.org/10.1083/jcb.200208023

[90] Xin, B., Platzer, P., Fink, S.P., Reese, L., Nosrati, A., Willson, J.K., Wilson, K. and Markowitz, S. (2005) Colon Cancer Secreted Protein-2 (CCSP-2), a Novel Candidate Serological Marker of Colon Neoplasia. Oncogene, 24, 724-731. http://dx.doi.org/10.1038/sj.onc.1208134

[91] Ardeleanu, C., Arsene, D., Hinescu, M., Andrei, F., Gutu, D., Luca, L. and Popescu, L.M. (2009) Pancreatic Expression of DOG1: A Novel Gastrointestinal Stromal Tumor (GIST) Biomarker. Applied Immunohistochemistry \& Molecular Morphology, 17, 413-418.

[92] Espinosa, I., Lee, C.H., Kim, M.K., Rouse, B.T., Subramanian, S., Montgomery, K., Varma, S., Corless, C.L., Heinrich, M.C., Smith, K.S., Wang, Z., Rubin, B., Nielsen, T.O., Seitz, R.S., Ross, D.T., West, R.B., Cleary, M.L. and Van De Rijn, M. (2008) A Novel Monoclonal Antibody against DOG1 Is a Sensitive and Specific Marker for Gastrointestinal Stromal Tumors. American Journal of Surgical Pathology, 32, 210-218. http://dx.doi.org/10.1097/PAS.0b013e3181238cec

[93] Wong, J.M., Mafune, K., Yow, H., Rivers, E.N., Ravikumar, T.S., Steele Jr., G.D. and Chen, L.B. (1993) UbiquitinRibosomal Protein S27a Gene Overexpressed in Human Colorectal Carcinoma Is an Early Growth Response Gene. Cancer Research, 53, 1916-1920.

[94] Fernandez-Pol, J.A. (1996) Metallopanstimulin as a Novel Tumor Marker in Sera of Patients with Various Types of Common Cancers: Implications for Prevention and Therapy. Anticancer Research, 16, 2177-2185.

[95] Atsuta, Y., Aoki, N., Sato, K., Oikawa, K., Nochi, H., Miyokawa, N., Hirata, S., Kimura, S., Sasajima, T. and Katagiri, M. (2002) Identification of Metallopanstimulin-1 as a Member of a Tumor Associated Antigen in Patients with Breast Cancer. Cancer Letters, 182, 101-107. http://dx.doi.org/10.1016/S0304-3835(02)00068-X

[96] Wang, Y.W., Qu, Y., Li, J.F., Chen, X.H., Liu, B.Y., Gu, Q.L. and Zhu, Z.G. (2006) In Vitro and in Vivo Evidence of Metallopanstimulin-1 in Gastric Cancer Progression and Tumorigenicity. Clinical Cancer Research, 12, 4965-4973. http://dx.doi.org/10.1158/1078-0432.CCR-05-2316

[97] Purrello, M., Di Pietro, C., Rapisarda, A., Amico, V., Giunta, V., Engel, H., Stevens, S., Hsieh, Y., Teichman, M., Wang, Z., Sichel, G., Roeder, R. and Grzeschik, K.H. (2001) Genes for Human General Transcription Initiation Factors TFIIIB, TFIIIB-Associated Proteins, TFIIIC2 and PTF/SNAPC: Functional and Positional Candidates for Tumour Predisposition or Inherited Genetic Diseases? Oncogene, 20, 4877-4883. http://dx.doi.org/10.1038/sj.onc.1204604

[98] Winter, A.G., Sourvinos, G., Allison, S.J., Tosh, K., Scott, P.H., Spandidos, D.A. and White, R.J. (2000) RNA Polymerase III Transcription Factor TFIIIC2 Is Overexpressed in Ovarian Tumors. Proceedings of the National Academy of Sciences of the United States of America, 97, 12619-12624. http://dx.doi.org/10.1073/pnas.230224097

[99] Jin, H., Wang, X., Ying, J., Wong, A.H., Cui, Y., Srivastava, G., Shen, Z.Y., Li, E.M., Zhang, Q., Jin, J., Kupzig, S., Chan, A.T., Cullen, P.J. and Tao, Q. (2007) Epigenetic Silencing of a Ca ${ }^{2+}$-Regulated Ras GTPase-Activating Protein RASAL Defines a New Mechanism of Ras Activation in Human Cancers. Proceedings of the National Academy of Sciences of the United States of America, 104, 12353-12358. http://dx.doi.org/10.1073/pnas.0700153104

[100] Skawran, B., Steinemann, D., Weigmann, A., Flemming, P., Becker, T., Flik, J., Kreipe, H., Schlegelberger, B. and Wilkens, L. (2008) Gene Expression Profiling in Hepatocellular Carcinoma: Upregulation of Genes in Amplified Chromosome Regions. Modern Pathology, 21, 505-516. http://dx.doi.org/10.1038/modpathol.3800998

[101] Zhou, F.L., Zhang, W.G., Chen, G., Zhao, W.H., Cao, X.M., Chen, Y.X., Tian, W., Liu, J. and Liu, S.H. (2006) Serological Identification and Bioinformatics Analysis of Immunogenic Antigens in Multiple Myeloma. Cancer Immunology, Immunotherapy, 55, 910-917. http://dx.doi.org/10.1007/s00262-005-0074-X

[102] Penna, I., Du, H., Ferriani, R. and Taylor, H.S. (2008) Calpain5 Expression Is Decreased in Endometriosis and Regulated by HOXA10 in Human Endometrial Cells. Molecular Human Reproduction, 14, 613-618. http://dx.doi.org/10.1093/molehr/gan055

[103] Ueki, T., Nakayama, Y., Sugao, Y., Kohno, K., Matsuo, K., Sugimoto, Y., Yamada, Y., Kuwano, M. and Tsuneyoshi, M. (1997) Significance of the Expression of Proliferation-Associated Nucleolar Antigen P120 in Human Colorectal Tumors. Human Pathology, 28, 74-79. http://dx.doi.org/10.1016/S0046-8177(97)90282-3

[104] Fonagy, A., Swiderski, C. and Freeman, J.W. (1995) Altered Transcription Control Is Responsible for the Increased Level of Proliferation-Associated P120 in Rapidly Growing Breast Carcinoma. International Journal of Cancer, 60, 407-412. http://dx.doi.org/10.1002/ijc.2910600323

[105] Sato, G., Saijo, Y., Uchiyama, B., Kumano, N., Sugawara, S., Fujimura, S., Sato, M., Sagawa, M., Ohkuda, K., Koike, K., Minami, Y., Satoh, K. and Nukiwa, T. (1999) Prognostic Value of Nucleolar Protein P120 in Patients with Resected Lung Adenocarcinoma. Journal of Clinical Oncology, 17, 2721-2727.

[106] Salahshor, S., Goncalves, J., Chetty, R., Gallinger, S. and Woodgett, J.R. (2005) Differential Gene Expression Profile Reveals Deregulation of Pregnancy Specific $\beta 1$ Glycoprotein 9 Early during Colorectal Carcinogenesis. BMC Cancer, 
5, 66. http://dx.doi.org/10.1186/1471-2407-5-66

[107] Heikinheimo, M., Rajantie, J., Kuusela, P., Kallio, M.J. and Siimes, M.A. (1990) Oncofetal Markers CA 19-9, CA 125 and SP1 in Healthy Children and in Children with Malignancy. British Journal of Cancer, 62, 865-867. http://dx.doi.org/10.1038/bjc.1990.396

[108] Wright, C., Angus, B., Napier, J., Wetherall, M., Udagawa, Y., Sainsbury, J.R., Johnston, S., Carpenter, F. and Horne, C.H. (1987) Prognostic Factors in Breast Cancer: Immunohistochemical Staining for SP1 and NCRC 11 Related to Survival, Tumour Epidermal Growth Factor Receptor and Oestrogen Receptor Status. Journal of Pathology, 153, 325331. http://dx.doi.org/10.1002/path.1711530406

[109] Kouji, H., Inazu, M., Yamada, T., Tajima, H., Aoki, T. and Matsumiya, T. (2009) Molecular and Functional Characterization of Choline Transporter in Human Colon Carcinoma HT-29 Cells. Archives of Biochemistry and Biophysics, 483, 90-98. http://dx.doi.org/10.1016/j.abb.2008.12.008

[110] Durany, N., Joseph, J., Campo, E., Molina, R. and Carreras, J. (1997) Phosphoglycerate Mutase, 2,3-Bisphosphoglycerate Phosphatase and Enolase Activity and Isoenzymes in Lung, Colon and Liver Carcinomas. British Journal of Cancer, 75, 969-977. http://dx.doi.org/10.1038/bjc.1997.168

[111] Fang, M.Z., Liu, C., Song, Y., Yang, G.Y., Nie, Y., Liao, J., Zhao, X., Shimada, Y., Wang, L.D. and Yang, C.S. (2004) Over-Expression of Gastrin-Releasing Peptide in Human Esophageal Squamous Cell Carcinomas. Carcinogenesis, 25, 865-871. http://dx.doi.org/10.1093/carcin/bgh097

[112] Pai, R., Dunlap, D., Qing, J., Mohtashemi, I., Hotzel, K. and French, D.M. (2008) Inhibition of Fibroblast Growth Factor 19 Reduces Tumor Growth by Modulating Beta-Catenin Signaling. Cancer Research, 68, 5086-5095. http://dx.doi.org/10.1158/0008-5472.CAN-07-2325

[113] Desnoyers, L.R., Pai, R., Ferrando, R.E., Hötzel, K., Le, T., Ross, J., Carano, R., D'Souza, A., Qing, J., Mohtashemi, I., Ashkenazi, A. and French, D.M. (2008) Targeting FGF19 Inhibits Tumor Growth in Colon Cancer Xenograft and FGF19 Transgenic Hepatocellular Carcinoma Models. Oncogene, 27, 85-97. http://dx.doi.org/10.1038/sj.onc.1210623

[114] Furuta, J., Nobeyama, Y., Umebayashi, Y., Otsuka, F., Kikuchi, K. and Ushijima, T. (2006) Silencing of Peroxiredoxin 2 and Aberrant Methylation of 33 CpG Islands in Putative Promoter Regions in Human Malignant Melanomas. Cancer Research, 66, 6080-6086. http://dx.doi.org/10.1158/0008-5472.CAN-06-0157

[115] Svensson, P., Bergqvist, I., Norlin, S. and Edlund, H. (2009) MFng Is Dispensable for Mouse Pancreas Development and Function. Molecular and Cellular Biology, 29, 2129-2138. http://dx.doi.org/10.1128/MCB.01644-08 
Scientific Research Publishing (SCIRP) is one of the largest Open Access journal publishers. It is currently publishing more than 200 open access, online, peer-reviewed journals covering a wide range of academic disciplines. SCIRP serves the worldwide academic communities and contributes to the progress and application of science with its publication.

Other selected journals from SCIRP are listed as below. Submit your manuscript to us via either submit@scirp.org or Online Submission Portal.
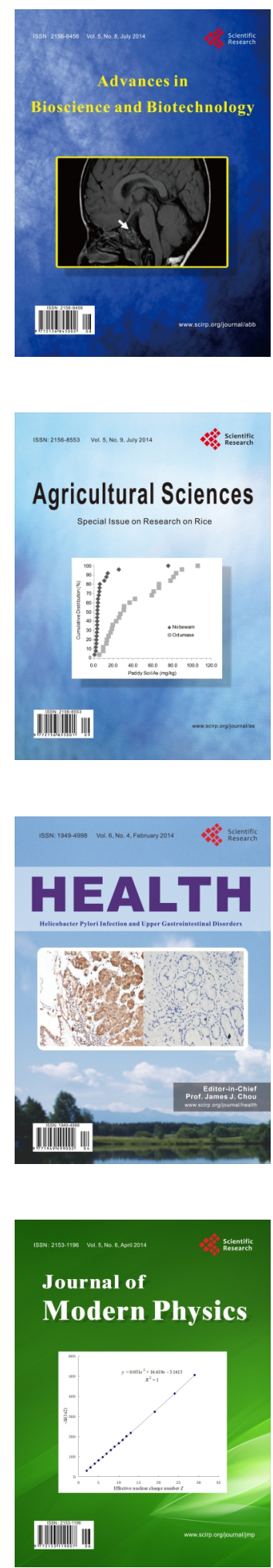
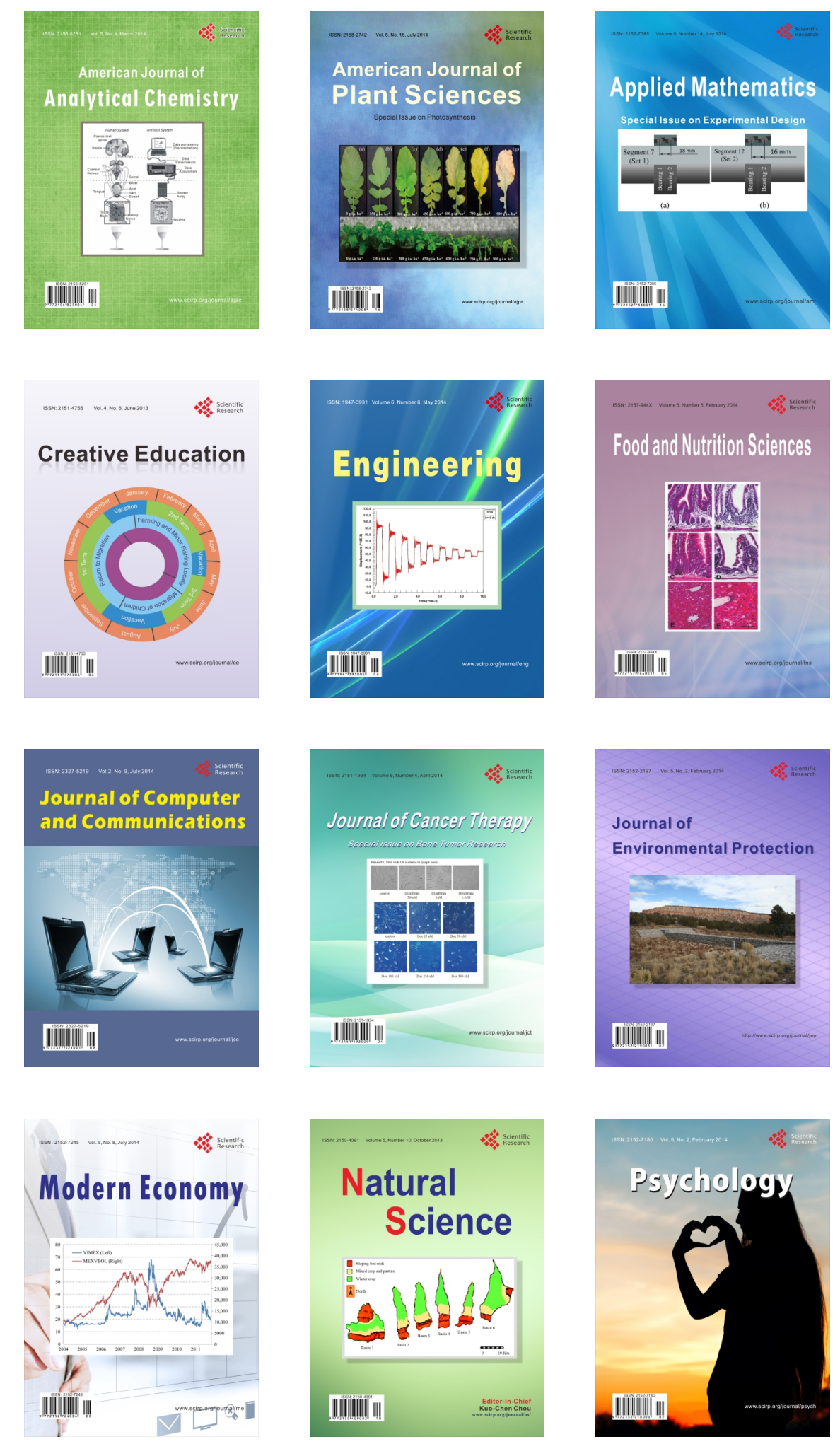